\title{
Recent progress in the racemic and enantioselective synthesis of monofluoroalkene-based dipeptide isosteres
}

\author{
Myriam Drouin and Jean-François Paquin ${ }^{*}$
}

\author{
Review \\ Address: \\ Département de chimie, Université Laval, 1045 avenue de la \\ Médecine, Pavillon Alexandre-Vachon, Québec (Québec) G1V 0A6, \\ Canada \\ Email: \\ Jean-François Paquin * jean-francois.paquin@chm.ulaval.ca \\ * Corresponding author \\ Keywords: \\ dipeptide isosteres; monofluoroalkene-based amide bonds; \\ monofluoroalkenes; peptides; synthesis
}

\author{
Beilstein J. Org. Chem. 2017, 13, 2637-2658. \\ doi:10.3762/bjoc. 13.262 \\ Received: 27 September 2017 \\ Accepted: 28 November 2017 \\ Published: 12 December 2017 \\ This article is part of the Thematic Series "Organo-fluorine chemistry IV". \\ Guest Editor: D. O'Hagan \\ (c) 2017 Drouin and Paquin; licensee Beilstein-Institut. \\ License and terms: see end of document.
}

\begin{abstract}
Monofluoroalkenes are fluorinated motifs that can be used to replace amide bonds. In order to be incorporated into peptides, it is normally necessary to first synthesize a dipeptide where the amide bond has been replaced with a monofluoroalkene. In that context, this review will present the racemic and enantioselective synthesis of monofluoroalkene-based dipeptide isosteres described since 2007. Some applications of those compounds will also be presented.
\end{abstract}

\section{Introduction}

Nowadays, the pharmaceutical industry is interested in the development of new categories of drugs. While small molecules were the principal targets in the last decades [1], larger biomolecules, such as peptides, are now widely studied [2,3]. The interest of these biopolymers originates, in part, from their high potency and selectivity towards the target, which results in a decrease of the toxicity and/or side effects. However, peptides have a poor metabolic stability [2].

A solution to enhance the stability of peptides is to modify their structure, in particular the amide bond linkage. Different moieties can be used as amide bond isosteres and some are illustrated in Figure 1 [4-6].
Of those amide bond isosteres, the monofluoroalkene is of particular interest as it possesses many relevant characteristics (Figure 2a). The resonance in the amide generates a double bond character between the carbon of the carbonyl and the nitrogen, which is responsible of the slow rotation around this bond. Furthermore, the negative charge is located on the oxygen atom and the dipole moment of the amide bond is 3.6 D [7]. The amide bond can also perform hydrogen bonds, with the oxygen atom as the hydrogen bond acceptor and $\mathrm{N}-\mathrm{H}$ as hydrogen bond donor. This characteristic is important for the formation of secondary structures and folding into tertiary and quaternary structures. To have a good amide bond isostere, these different aspects should be reproduced, which is mostly the case 


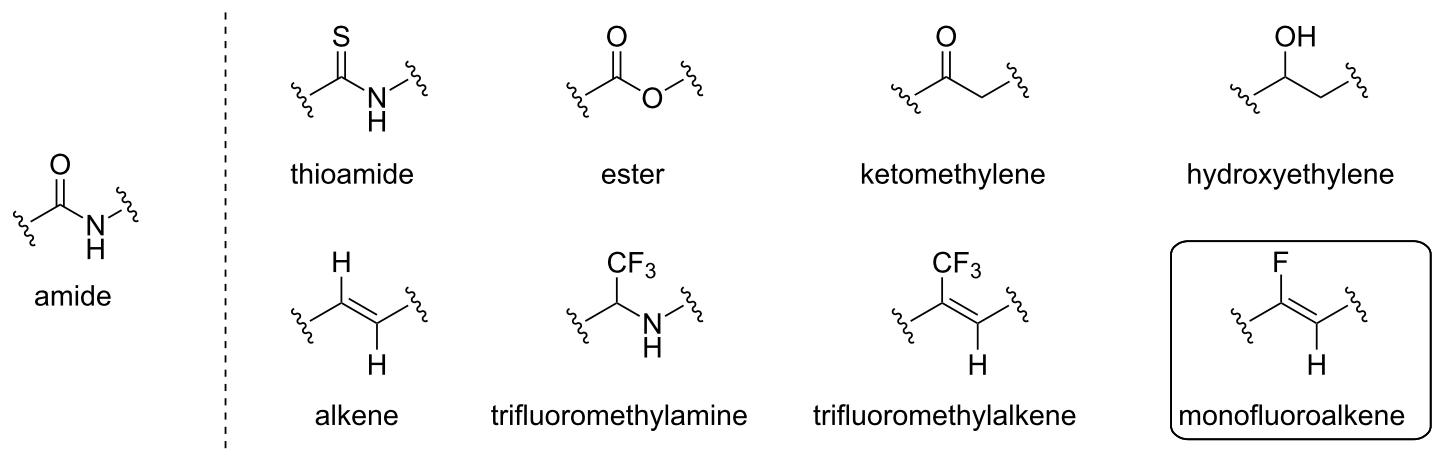

Figure 1: Selected amide bond isosteres.

with the monofluoroalkene moiety [8]. The monofluoroalkene is a rigid molecule as it possesses a double bond. Furthermore, the fluorine atom bears a partial negative charge, with a dipole moment of 1.4 D. Finally, the monofluoroalkene has the ability to accept a hydrogen bond through the fluorine atom [9]. Geometrically, the monofluoroalkene is quite similar to the amide bond. The $\mathrm{C}=\mathrm{O}$ bond of the amide is $1.228 \AA$, compared to $1.376 \AA$ for the $\mathrm{C}-\mathrm{F}$ bond, and the $\mathrm{C}-\mathrm{N}$ bond is $1.368 \AA$ compared to $1.333 \AA$ for the $\mathrm{C}=\mathrm{C}$ bond [5,10-12]. Also, the amide structure is found in Nature as the s-trans or s-cis isomer, which can be in equilibrium (Figure 2b) [13]. However, most of the time it is found as the s-trans isomer to minimize steric interaction and to favour a linear and less hindered shape [14]. A notable exception is found in the case of the proline, where the s-cis isomer is favoured [15]. With the monofluoroalkene moiety, it is possible to mimic selectively one or the other isomer as no equilibrium exists between them. As such, the (Z)monofluoroalkene is an analogue of the s-trans amide bond, while the $(E)$-monofluoroalkene mimics the s-cis form.

Considering those favourable properties, monofluoroalkenes constitute an interesting amide bond isostere, thus many researches have investigated their synthesis and application [16-22]. In order to be incorporated into peptides, it is normally necessary to first synthesize a dipeptide where the amide bond has been replaced with a monofluoroalkene. This review is the follow-up of the last one published by Taguchi and Yanai in 2009 which covered the literature until 2007 [5] and will discuss the new developments on the racemic and enantioselective synthesis of monofluoroalkene-based dipeptide isosteres from 2008 to September 2017. First, synthetic approaches to analogues in which there is no side chain or where the side chain stereochemistry is not controlled will be highlighted. This will be followed by the presentation of the synthesis of analogues where the side chain stereochemistry is controlled. In both cases, the review will be divided according to the monofluoro- a) monofluoroalkene as a replacement of the amide bond

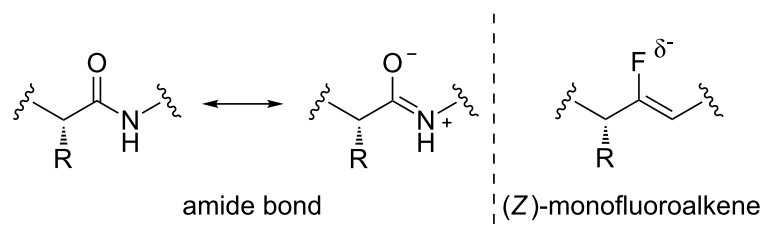

b) conformation of the amide bond and of the monofluoroalkene

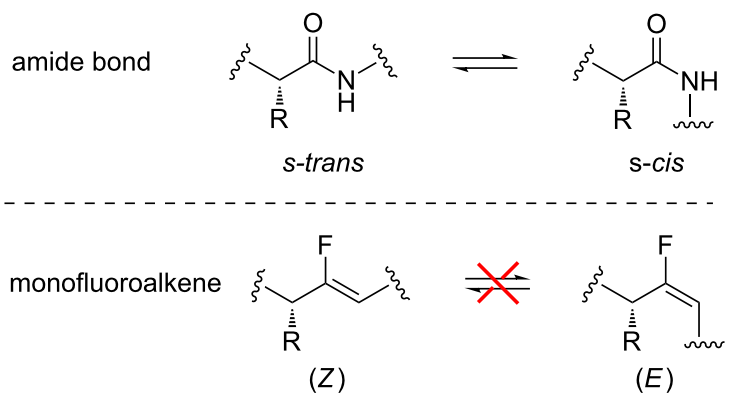

Figure 2: Monofluoroalkene as an amide bond isostere.

alkene-based dipeptide isosteres prepared. Finally, recent applications will be described.

\section{Review}

Analogues in which there is no side chain or where the side chain stereochemistry is not

\section{controlled}

\section{Gly- $\psi[\mathrm{CF}=\mathrm{CH}]-\mathrm{Gly}$}

The Gly- $\psi[\mathrm{CF}=\mathrm{CH}]-\mathrm{Gly}$ analogue is the simplest one, as it does not present side chains. Its synthesis was performed by two groups, using in both cases an olefination reaction. Sano's group was interested in the Horner-Wadsworth-Emmons (HWE) olefination to develop the synthesis of $\alpha$-fluoro- $\alpha, \beta$ - 
unsaturated ester $\mathbf{3}$, which can be used as a precursor for the synthesis of monofluoroalkene-based dipeptide isosteres [23]. Cbz-Gly- $\psi[(Z)-\mathrm{CF}=\mathrm{CH}]$-Gly 5 was obtained in seven steps (Scheme 1). First, triethyl 2-fluoro-2-phosphonoacetate (1) was converted into the $\alpha$-fluoro- $\alpha, \beta$-unsaturated carbonyl $\mathbf{3}$ using the HWE olefination. The $(Z)$-isomer was obtained with complete selectivity. Then, reduction of the ester into the corresponding alcohol followed by a Mitsunobu reaction allowed the insertion of the NH-carboxybenzyl moiety to afford 4. Finally, removal of the tert-butyldiphenylsilyl group using tert- $n$-butylammonium fluoride, followed by oxidation with the Jones reagent, provided the $C$-terminal carboxylic acid $\mathbf{5}$.
In 2011, Lequeux and co-workers used rather the Julia-Kocienski olefination to access Phth-Gly- $\psi[\mathrm{CF}=\mathrm{CH}]-\mathrm{Gly}$ 9, from benzothiazolyl fluoroaminosulfones (Scheme 2) $[24,25]$. The Julia-Kocienski olefination of 3-alkoxypropanal 7 with phthalimido sulfone 6 afforded the corresponding monofluoroalkene 8 as a $(Z):(E)$ mixture (54:46). Removal of the benzyl group using titanium tetrachloride gave the free alcohol which was oxidized to provide the N-protected dipeptide isostere 9. Some limitations were observed towards the compatibility of the N-protecting groups and in particular, $N$-tertbutoxycarbonyl-protected amines were not compatible with this methodology.

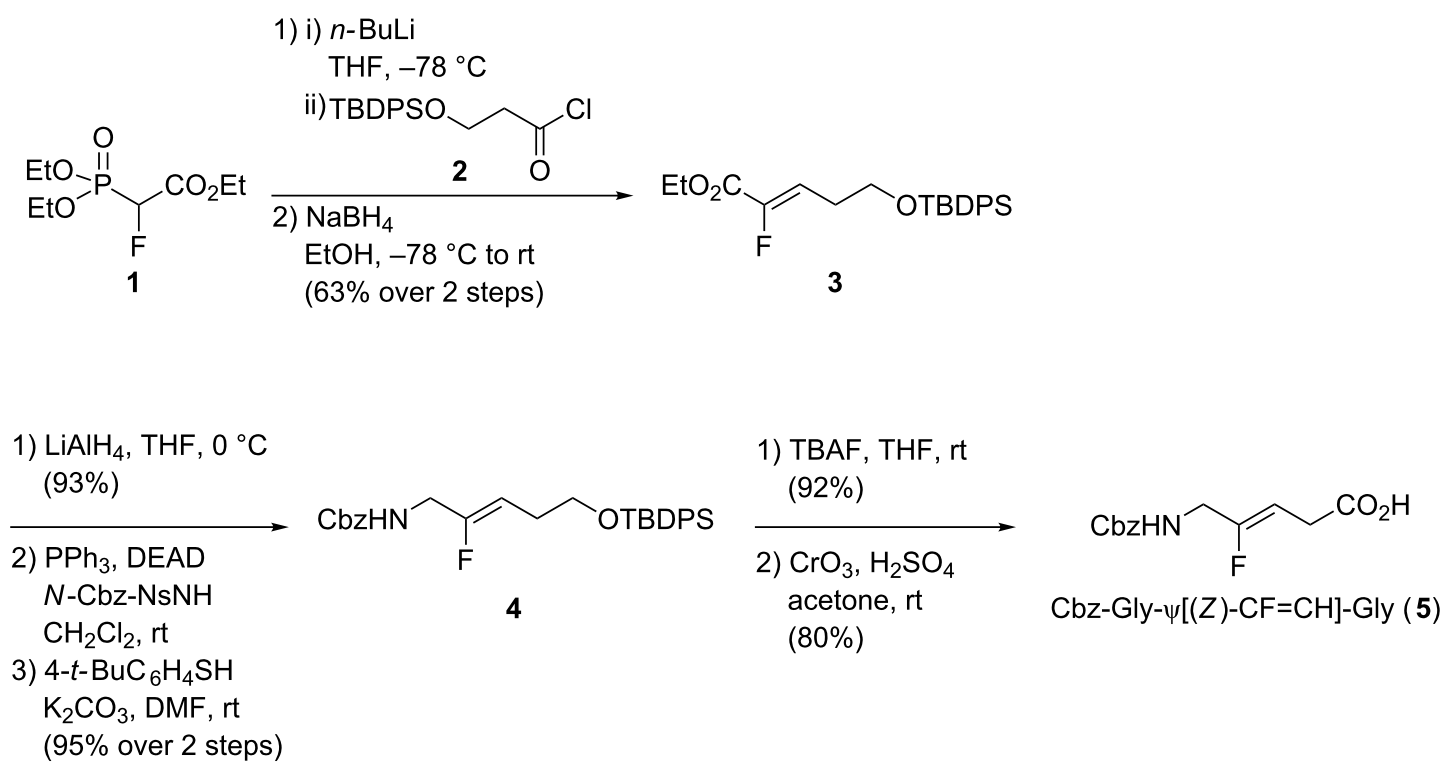

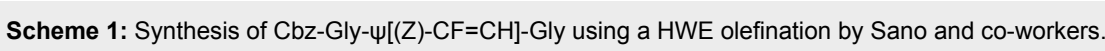

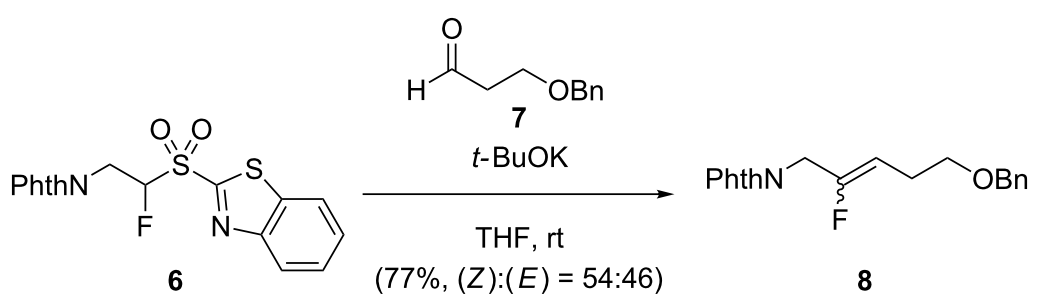

1) $\mathrm{TiCl}_{4}, \mathrm{CH}_{2} \mathrm{Cl}_{2}, \mathrm{rt}$

$(90 \%)$

2) $\begin{aligned} & \mathrm{CrO}_{3}, \mathrm{H}_{2} \mathrm{SO}_{4} \\ & \text { acetone, } \mathrm{rt} \\ & (85 \%)\end{aligned}$
Phth-Gly- $\psi[\mathrm{CF}=\mathrm{CH}]-\mathrm{Gly}(9)$ 


\section{Xaa- $\psi[\mathrm{CF}=\mathrm{CH}]-\mathrm{Gly}$}

To access $\mathrm{Xaa}-\psi[\mathrm{CF}=\mathrm{CH}]$-Gly isosteres, a $\mathrm{S}_{\mathrm{N}} 2$ ' reaction upon 3,3-difluoropropene substrates can be used, as shown by Taguchi's group. The synthesis of monofluoroalkenes starting from 3,3-difluoropropenes and using trialkylaluminium reagents was developed. Using this methodology, they were able to prepare Boc-Nva- $\psi[\mathrm{CF}=\mathrm{CH}]$-Gly isostere [26] via a $\mathrm{S}_{\mathrm{N}} 2$ ' reaction (Scheme 3). The defluorinative allylic alkylation of terminal 3,3-difluoropropene $\mathbf{1 0}$ with triethylaluminium selectively provided the corresponding $(Z)$-monofluoroalkene 11. In this case, the use of $\mathrm{Et}_{3} \mathrm{Al}$ allowed access to a norvaline (Nva) isostere. Then, alcohol 11 was converted into the trichloroimidate, and heating in xylenes permitted a [3,3]-sigmatropic rearrangement. At this stage, the trichloroimidate was transformed into an NHBoc moiety. Deprotection of the alcohol followed by Jones oxidation gave the final dipeptide isostere $\mathbf{1 3}$.

Taguchi and co-workers proposed a variant of the defluorinative reaction using heteroatom nucleophiles using aluminumbased reagents such as $\mathrm{Me}_{2} \mathrm{AlCl}$ and $(\mathrm{iPrO})_{2} \mathrm{AlN}_{3}$, and $(Z)$ selectivity was observed for the formation of the monofluoroalkene [27]. When dimethylaluminum chloride was used, the resulting allylic chloride reacted easily in a $\mathrm{S}_{\mathrm{N}} 2$ reaction to give a more functionalized molecule. For example, treatment of the chlorinated monofluoroalkene with $\mathrm{NaN}_{3}$ provided the corresponding $\mathrm{N}_{3}$-containing monofluoroalkene. The azide group underwent a 1,3-dipolar cycloaddition to give a 1,2,3-triazole, which is also a peptide bond isostere [6]. Using this strategy, a mutant tripeptide containing two different peptide bond isosteres could be synthesized (Figure 3).

In 2016, Konno and co-workers developed a stereoselective chromium-mediated $\mathrm{C}-\mathrm{F}$ bond cleavage followed by a $\mathrm{C}-\mathrm{C}$ bond formation to access $(Z)$-monofluoroalkenes with

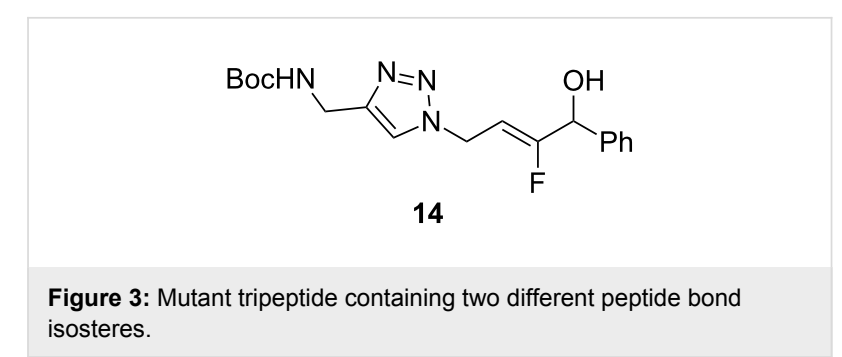

excellent selectivity (Scheme 4) [28]. The chromium-mediated coupling of 1-bromo-4-(tert-butyldiphenylsiloxy)-1,1-difluorobutane (15) with aldehyde $\mathbf{1 6}$ led to the formation of monofluoroalkene 17. This was then reacted with sodium azide and a further Staudinger reduction gave 18. Boc protection of the resulting amine 18, cleavage of the alcohol protecting group, Jones oxidation and formation of the methyl ester afforded the corresponding dipeptide isostere Boc-Ser(PMB)- $\psi[(Z)-$ $\mathrm{CF}=\mathrm{CH}]-$ Gly-OMe (19). In the same way, Boc-Val- $\psi[(Z)-$ $\mathrm{CF}=\mathrm{CH}]-$ Gly-OMe, Boc-Leu- $\psi[(Z)-\mathrm{CF}=\mathrm{CH}]-$ Gly-OMe and Boc-Ala- $\psi[(Z)-\mathrm{CF}=\mathrm{CH}]-\mathrm{Gly}-\mathrm{OMe}$ were prepared.

\section{Xaa- $\Psi[\mathrm{CF}=\mathrm{C}]-$ Pro}

The methodologies presented in the last decades used the olefination of cyclopentanone derivatives as the key step to access Xaa- $\psi[\mathrm{CF}=\mathrm{C}]-$ Pro, via either a Peterson olefination or a HWE olefination [29-31]. In all cases, the selectivity was modest and the isomers had to be separated by flash chromatography. In 2014, Sano and co-workers reported a selective synthesis of $\mathrm{Xaa}-\psi[\mathrm{CF}=\mathrm{C}]-$ Pro with a new cyclopentanone derivative $\mathbf{2 0}$ bearing a bulky 2-(4-methyl-2,6,7-trioxabicyclo[2.2.2]octan-1yl) group (OBO), which favoured the formation of the $(E)$ isomer in the HWE olefination (Scheme 5). The (E)-monofluoroalkene was thus obtained in an excellent selectivity using $n$-butyllithium in tert-butyl methyl ether. The resulting ester 21

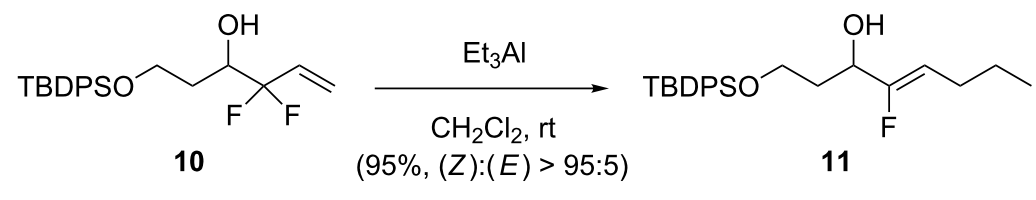

1) $\mathrm{Cl}_{3} \mathrm{CCN}, \mathrm{DBU}$

2) xylenes, $\Delta$ (43\% over 2 steps)

3) $\mathrm{NaOH}, \mathrm{H}_{2} \mathrm{O} / \mathrm{EtOH}$, rt

4) $\mathrm{Boc}_{2} \mathrm{O}, \mathrm{Et}_{3} \mathrm{~N}$

$\mathrm{CH}_{2} \mathrm{Cl}_{2}$, rt

( $76 \%$ over 2 steps)<smiles>CCCC(NC(=O)OCc1ccccc1)/C(F)=C/CCO[R5](C)(C)C</smiles>

12
1) TBAF THF, rt $(90 \%)$

2) $\mathrm{CrO}_{3}$ $\mathrm{H}_{2} \mathrm{SO}_{4}$ acetone $(75 \%)$<smiles>CCCC(NC(=O)OCc1ccccc1)/C(F)=C/CC(=O)O</smiles>

Boc-Nva- $\psi[(Z)-C F=C H]-G l y ~(13)$ 


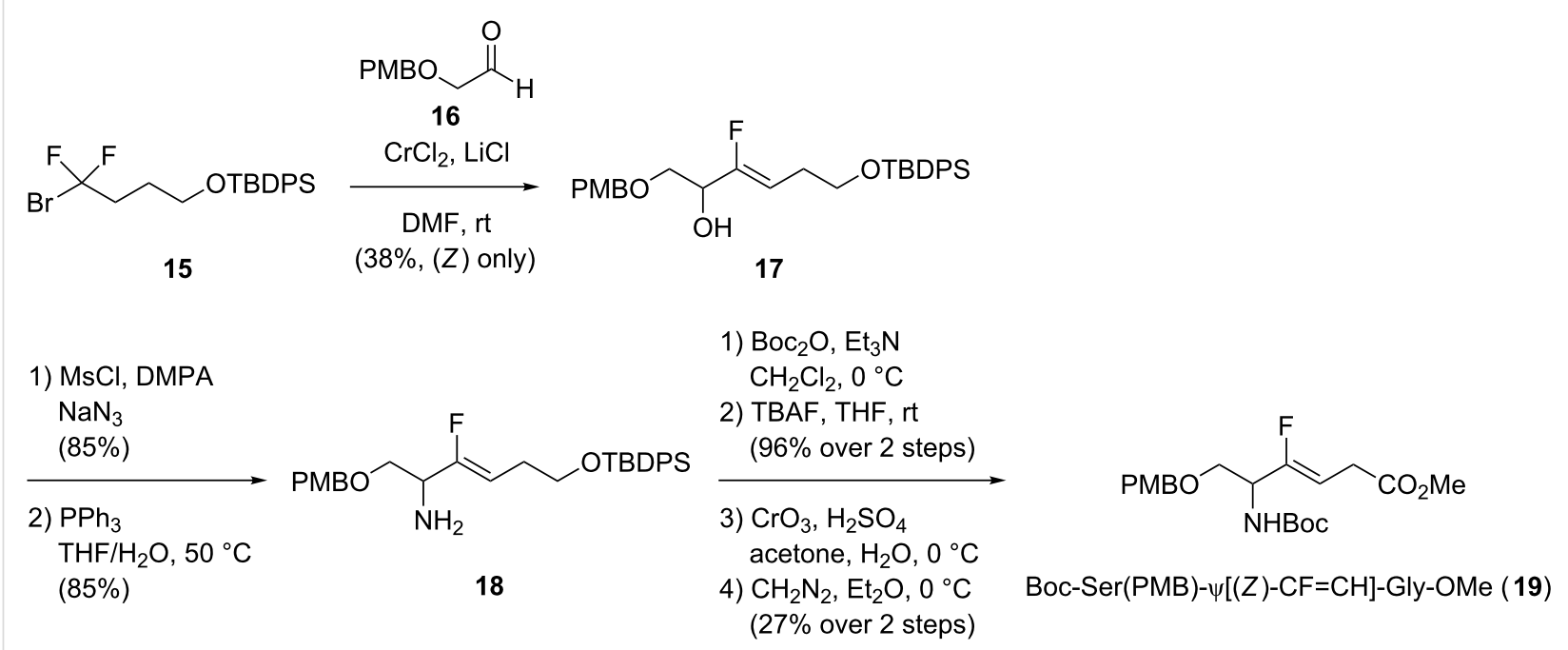

Scheme 4: Chromium-mediated synthesis of Boc-Ser(PMB)- $\Psi[(Z)-C F=C H]-G l y-O M e$ by Konno and co-workers.

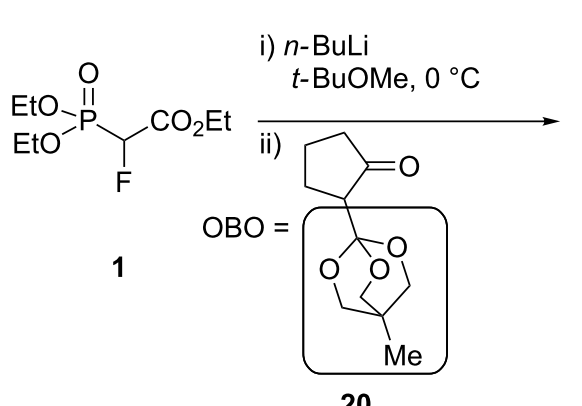

20

$(94 \%,(Z):(E)=5: 95)$

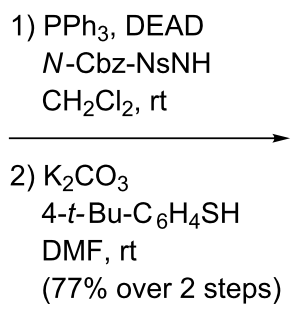<smiles>CCOC(=O)OC1CCC/C1=C(\F)C(=O)OCC</smiles>

21

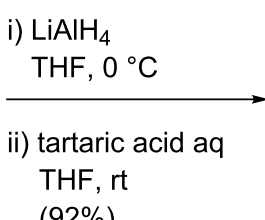

$(92 \%)$

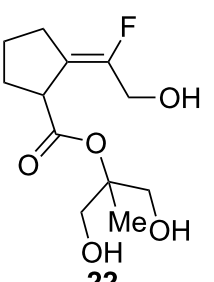

22

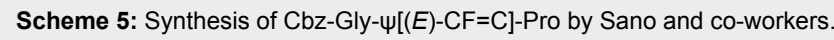

was reduced using lithium aluminum hydride, and treatment with tartaric acid deprotected the OBO, thus providing the free triol 22. This was then converted into a protected amino group employing a Mitsunobu reaction. Finally, removal of the nosyl group, followed by hydrolysis using lithium hydroxide, afforded the targeted isostere $\mathbf{2 4}$.

Sano and co-workers also worked on the $\mathrm{Mg}(\mathrm{II})$-promoted stereoselective synthesis of (Z)-monofluoroalkenes (Scheme 6)
[32,33]. HWE olefination promoted by $\mathrm{Mg}(\mathrm{II})$ of (diethoxyphosphoryl)fluoroacetic acid (25) with triisopropylsilyl-protected 2-hydroxymethylcyclopentanone $\mathbf{2 6}$ was realized with excellent yield and stereoselectivity. Esterification of the resulting carboxylic acid $\mathbf{2 7}$ into the corresponding methyl ester using trimethylsilyldiazomethane, followed by its reduction to the corresponding alcohol and a Mitsunobu reaction, permitted the incorporation of the N-terminal moiety. Then, removal of the Ns group of $\mathbf{2 8}$ and deprotection of the primary alcohol was 


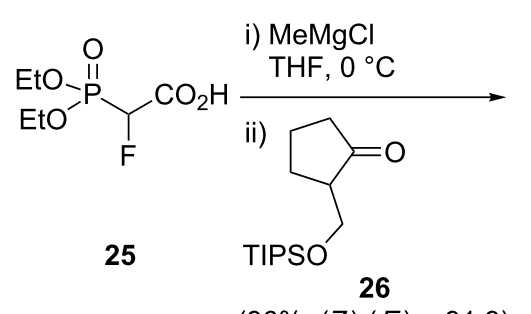

$(96 \%,(Z):(E)=91: 9)$<smiles>O=C(O)/C(F)=C1\CCCC1CO[SH](=[Rh])=[Te]</smiles>

27
1) $\mathrm{TMSCHN}_{2}$

$\mathrm{MeOH} /$ benzene, $\mathrm{rt}$

2) $\mathrm{LiAlH}_{4}, \mathrm{THF}, 0^{\circ} \mathrm{C}$ (99\% over 2 steps)

3) $\mathrm{PPh}_{3}$, DIAD

$\mathrm{N}-\mathrm{Cbz}-\mathrm{NsNH}$

$\mathrm{CH}_{2} \mathrm{Cl}_{2}$, rt

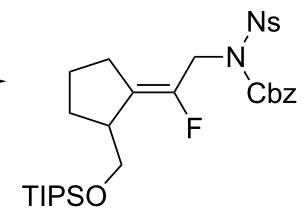

28

1) $\mathrm{K}_{2} \mathrm{CO}_{3}$

4- $t-\mathrm{Bu}-\mathrm{C}_{6} \mathrm{H}_{4} \mathrm{SH}$

DMF, rt

(83\% over 2 steps)

2) TBAF, THF, rt $(100 \%)$<smiles>O=C(NCC(F)=C1CCCC1CO)OCc1ccccc1</smiles>

29

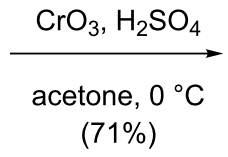

$(71 \%)$<smiles>O=C(O)NCC(F)=C1CCCC1C(=O)O</smiles>

Cbz-Gly- $\psi[(Z)-C F=C]-P r o ~(30)$

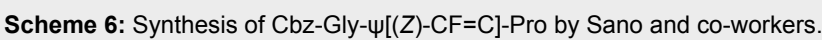

performed to obtain $\mathbf{2 9}$ which underwent a Jones oxidation to give the final dipeptide isostere $\mathbf{3 0}$.

\section{Analogues in which the side chain stereochemistry is controlled Gly- $\psi[\mathrm{CF}=\mathrm{CH}]-\mathrm{Xaa}$}

Different strategies have been used over the years to access Gly $-\psi[\mathrm{CF}=\mathrm{CH}]-\mathrm{Xaa}$ isosteres in which the side chain stereochemistry of the Xaa is controlled. This could be achieved using an olefination reaction, a metathesis reaction or a copper-medi- ated reduction of 3,3-difluoropropenes. Pannecoucke's group employed a chiral auxiliary, the Evans oxazolidinone, to prepare the non-racemic dipeptide isostere 35 (Scheme 7) [34]. Stereoselective alkoxymethylation on the oxazolidinone derivative 31 was first achieved with an excellent yield (88\%) and diastereoselectivity (de $>95 \%$ ). The chiral auxiliary was then removed and the free alcohol was oxidized to the corresponding aldehyde 32. Alkene $\mathbf{3 3}$ was then obtained after olefination of 32 with low selectivity $((Z):(E)=64: 36)$. The resulting ester 33 was then reduced to the corresponding aldehyde, followed

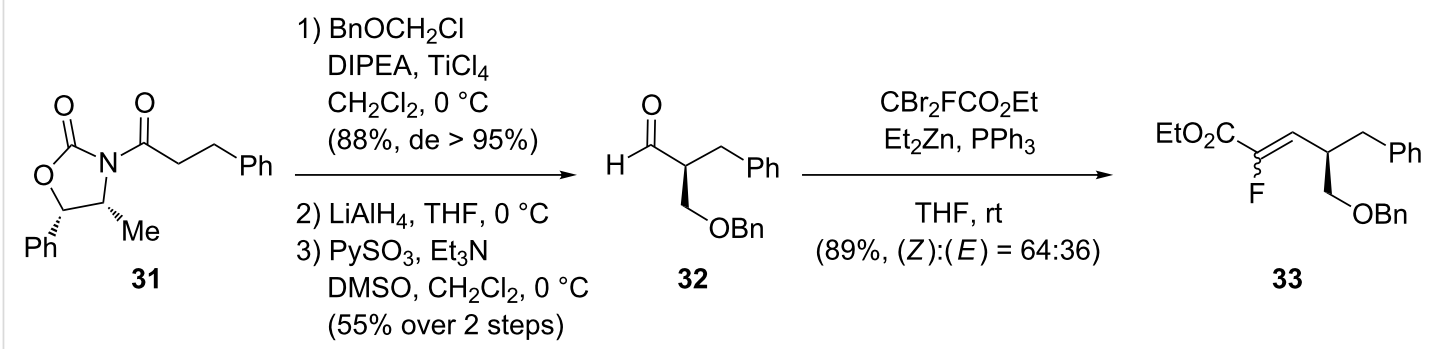

\section{1) $\mathrm{LiAlH}_{4}, \mathrm{THF}, 0^{\circ} \mathrm{C}$ \\ 2) $\mathrm{PySO}_{3}, \mathrm{Et}_{3} \mathrm{~N}$ DMSO, $\mathrm{CH}_{2} \mathrm{Cl}_{2}, 0^{\circ} \mathrm{C}$ (70\% over 2 steps)}

3) $t$ - $\mathrm{BuSONH}_{2}$ $\mathrm{Ti}(\mathrm{OEt})_{4}, \mathrm{THF}, 65^{\circ} \mathrm{C}$ $(95 \%)$

4) $\mathrm{NaBH}_{4}, \mathrm{THF}, 0^{\circ} \mathrm{C}$ $(95 \%)$<smiles>CC(C)(C)S(=O)NC/C(F)=C/C(COc1ccccc1)Cc1ccccc1</smiles>

34
1) $\mathrm{BCl}_{3}, \mathrm{CH}_{2} \mathrm{Cl}_{2},-78^{\circ} \mathrm{C}$ (58\%)

2) $\mathrm{HCl}$ (4 $\mathrm{M}$ in dioxane), $\mathrm{MeOH}, \mathrm{rt}$ $(100 \%)$

3) Fmoc-OSu, $\mathrm{NaHCO}_{3}$ dioxane $/ \mathrm{H}_{2} \mathrm{O}, 0^{\circ} \mathrm{C}$

(95\%)

4) $\mathrm{CrO}_{3}, \mathrm{H}_{2} \mathrm{SO}_{4}$, acetone, $0{ }^{\circ} \mathrm{C}$ $(80 \%)$

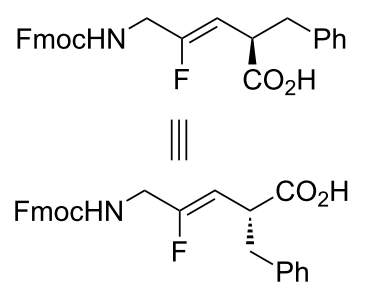

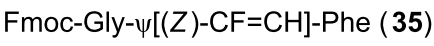


by the formation of the terminal imine and its subsequent reduction to access the N-terminal moiety of $\mathbf{3 4}$. The alcohol and the amine deprotections were then achieved, followed by reprotection of the amine with a fluorenylmethyloxycarbonyl group. Oxidation of the remaining alcohol to the corresponding carboxylic acid provided the dipeptide isostere $\mathbf{3 5}$.

Couve-Bonnaire and co-workers developed the preparation of (E)-monofluoroalkene dipeptide isosteres towards an intramolecular ring-closure metathesis (Scheme 8) [35]. The bis-alkene 36 underwent a ring-closure metathesis reaction in the presence of catalyst $\mathbf{3 7}$ under microwave irradiation to give lactam $\mathbf{3 8}$. Deprotection of the amine followed by acidic opening of the ring gave the $(E)$-monofluoroalkene 39 in good yield. The reac- tion was also performed on the racemic starting material to confirm that the process did not induce any epimerization. This methodology was then extended to the synthesis Gly- $\psi[(E)-$ $\mathrm{CF}=\mathrm{CH}]-$ Gly (not shown).

Finally, Dory and co-workers reported the synthesis of FmocGly- $\psi[(Z)-\mathrm{CF}=\mathrm{CH}]$-Phe (Scheme 9) [36]. Their work was inspired by the methodology reported by Fujii, Otaka and co-workers, which showed that the sultam moiety is a useful chiral auxiliary to control the stereochemistry during the incorporation of the lateral chain (see Scheme 15) [37]. The coppermediated reduction of 3,3-difluoropropene $\mathbf{4 0}$ bearing a sultam (Xs) as a chiral auxiliary followed by $\alpha$-alkylation afforded the monofluoroalkene 41. Hydrolysis of the chiral auxiliary fol-<smiles>C=CCC(=O)N(C)OC(C)(C)C</smiles>

36<smiles>CCCCN1C(=O)CC=C(F)C1c1ccccc1</smiles>

38
1) $\mathrm{CAN}$

$\mathrm{MeCN} / \mathrm{H}_{2} \mathrm{O}, \mathrm{rt}$

$(76 \%)$

2) $\mathrm{HCl}(6 \mathrm{M})$, reflux (quant.)<smiles>N[C@@H](/C(F)=C\CC(=O)O)c1ccccc1</smiles>

Gly- $\psi[(E)-\mathrm{CF}=\mathrm{CH}]-\mathrm{Phg}$

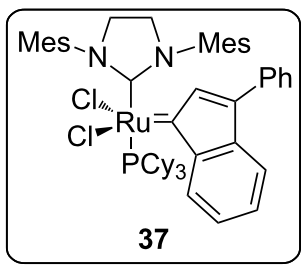

Scheme 8: Ring-closure metathesis to prepare $\mathrm{Gly}-\Psi[(E)-\mathrm{CF}=\mathrm{CH}]-\mathrm{Phg}$ by Couve-Bonnaire and co-workers.
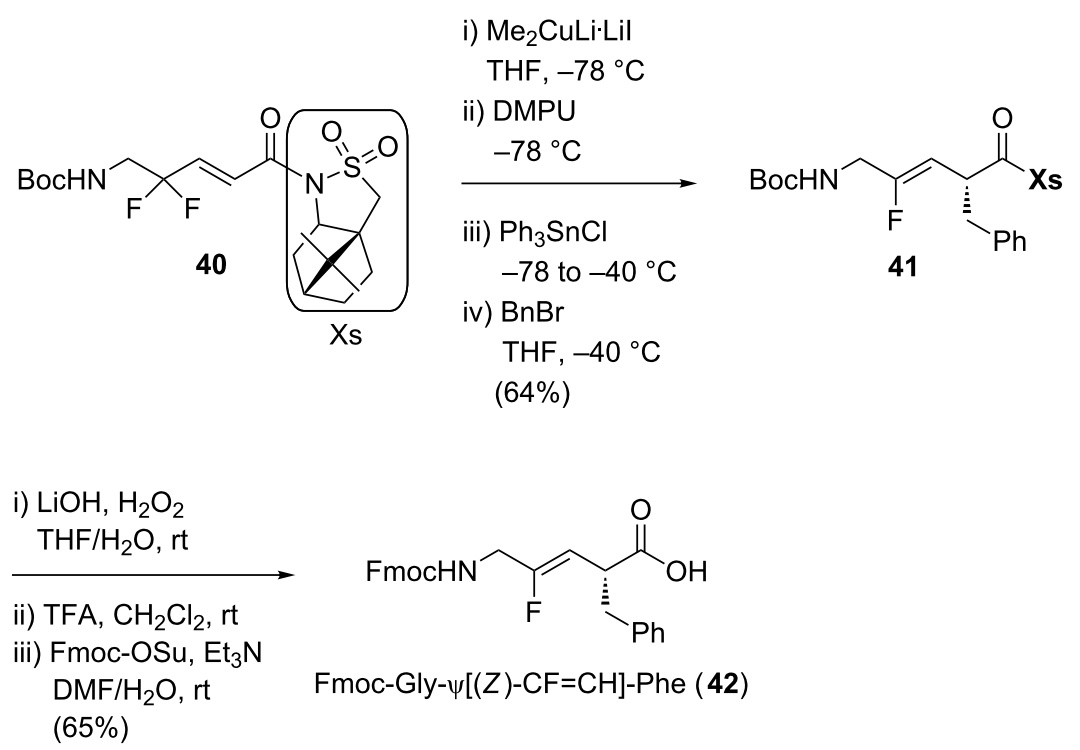

DMF/<smiles>O=CNC/C(F)=C/[C@H](Cc1ccccc1)C(=O)O</smiles>

Fmoc-Gly- $\psi[(Z)-C F=C H]-P h e(42)$ 
lowed by deprotection of the Boc-protected amine and its subsequent reprotection by a Fmoc group gave the final dipeptide isostere $\mathbf{4 2}$.

\section{Xaa- $\psi[\mathrm{CF}=\mathrm{CH}]-\mathrm{Gly}$}

The development of new methodologies to access Xaa$\psi[\mathrm{CF}=\mathrm{CH}]$-Gly isosteres with control of the stereochemistry at the side chain will be discussed in this section. In particular, olefination reaction, defluorinative reduction of 3,3-difluoropropene derivatives and electrophilic fluorination of alkenylstannanes are presented. Pannecoucke's group described the synthesis of monofluoroalkenes from $\alpha$-fluoro- $\alpha, \beta$-unsaturated aldehydes 45 , which are more easily accessible than the corresponding enones (Scheme 10) [38]. Their synthesis started with the olefination of aldehyde $\mathbf{4 3}$ which gave the corresponding monofluoroalkene 44. Reduction with subsequent oxidation of the ester gave the corresponding aldehyde $\mathbf{4 5}$ which was then transformed into the $\alpha$-fluoroenimine 47 . This was selectively converted into the corresponding sulfinylamines using Grignard reagents to access $(S)$-amino acids 48 , while addition of organolithium reagents gave $(R)$-amino acids. A sequence of $\mathrm{N}$ - and $\mathrm{O}$-deprotection, $\mathrm{N}$-Fmoc-protection and oxidation to the carboxylic acid afforded the final Fmoc-Ala- $\psi[(Z)-\mathrm{CF}=\mathrm{CH}]-$ Gly (49).
Then, it was discovered that the diastereoselectivity of the addition of the Grignard reagent on 47 was enhanced when dimethylzinc $\left(\mathrm{Me}_{2} \mathrm{Zn}\right)$ was used as an additive (Table 1) [39]. Indeed, triorganozincates $\left(\mathrm{Me}_{2}(\mathrm{R}) \mathrm{ZnMgX}\right)$ were formed in situ and these reagents activated favourably the substrates towards the stereoselective addition of the alkyl chain.

To prepare Boc-Val- $\psi[(Z)-\mathrm{CF}=\mathrm{CH}]-\mathrm{Gly}-\mathrm{OEt}$, Otaka's group developed an intramolecular redox reaction of 3,3-difluoropropenes using N-heterocyclic carbenes (NHCs, Scheme 11) [40]. The reaction was first performed on the $\gamma, \gamma$-difluoro- $\alpha, \beta$ enal 52 which was synthesized via a Wittig olefination of $\mathbf{5 0}$. The resulting monofluoroalkene Boc-Val- $\psi[(Z)-\mathrm{CF}=\mathrm{CH}]-\mathrm{Gly}-$ OEt was obtained in good yield. Afterwards, the $\gamma, \gamma$-difluoro$\alpha, \beta$-enoylsilane 55, obtained after HWE olefination using dimethyl phosphonoacylsilane $\mathbf{5 4}$, was found to facilitate the NHC-catalyzed reduction and gave in this way the dipeptide isostere $\mathbf{5 6}$ in excellent yield.

The defluorinative reduction could also be performed using samarium iodide. Altman and co-workers proposed the synthesis of Boc-Tyr- $\psi[(Z)-\mathrm{CF}=\mathrm{CH}]-\mathrm{Gly}$ using a diastereoselective Reformatsky-Honda condensation, a $(E)$-selective HWE olefination and $\mathrm{SmI}_{2}$ reduction as key steps (Scheme 12) [41].

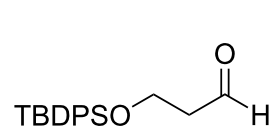

43

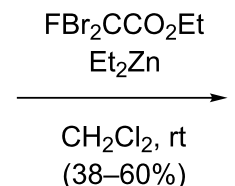

(38-60\%)<smiles>CCOC(=O)/C(F)=C/CCO[R5](=O)[O-]</smiles>

44
1) DIBAL

THF, $-78^{\circ} \mathrm{C}$ (quant.)

2) $\mathrm{SO}_{3} \cdot$ pyridine DMSO, $\mathrm{Et}_{3} \mathrm{~N}$ $\mathrm{CH}_{2} \mathrm{Cl}_{2}, 0^{\circ} \mathrm{C}$ (82-89\%)<smiles>CC(C)(C)[Sb]OCC/C=C(\F)C=O</smiles>

(89-96\%)

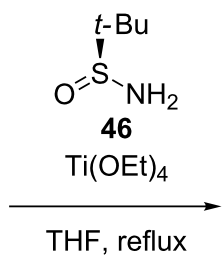

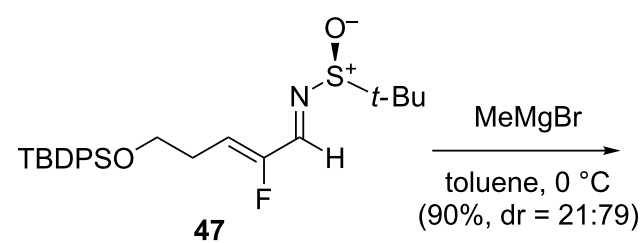<smiles>CC(C)COCCC/C=C(\F)C(C)N[S+]([O-])C(C)(C)C</smiles>

1) $\mathrm{HCl}(4 \mathrm{M})$ dioxane, it

2) $\mathrm{FmocOSu}, \mathrm{NaHCO}_{3}$ dioxane $/ \mathrm{H}_{2} \mathrm{O}, 0^{\circ} \mathrm{C}$

3) Jones oxidation ( $71 \%$ over 3 steps)<smiles>CC(NC=O)/C(F)=C/CC(=O)O</smiles>

Fmoc-Ala- $\psi[(Z)-C F=C H]-G l y ~(49)$ 
Table 1: Diastereoselective addition of Grignard reagents to sulfinylamines derived from $\alpha$-fluoroenals with $\mathrm{Me}_{2} \mathrm{Zn}$ as additive.

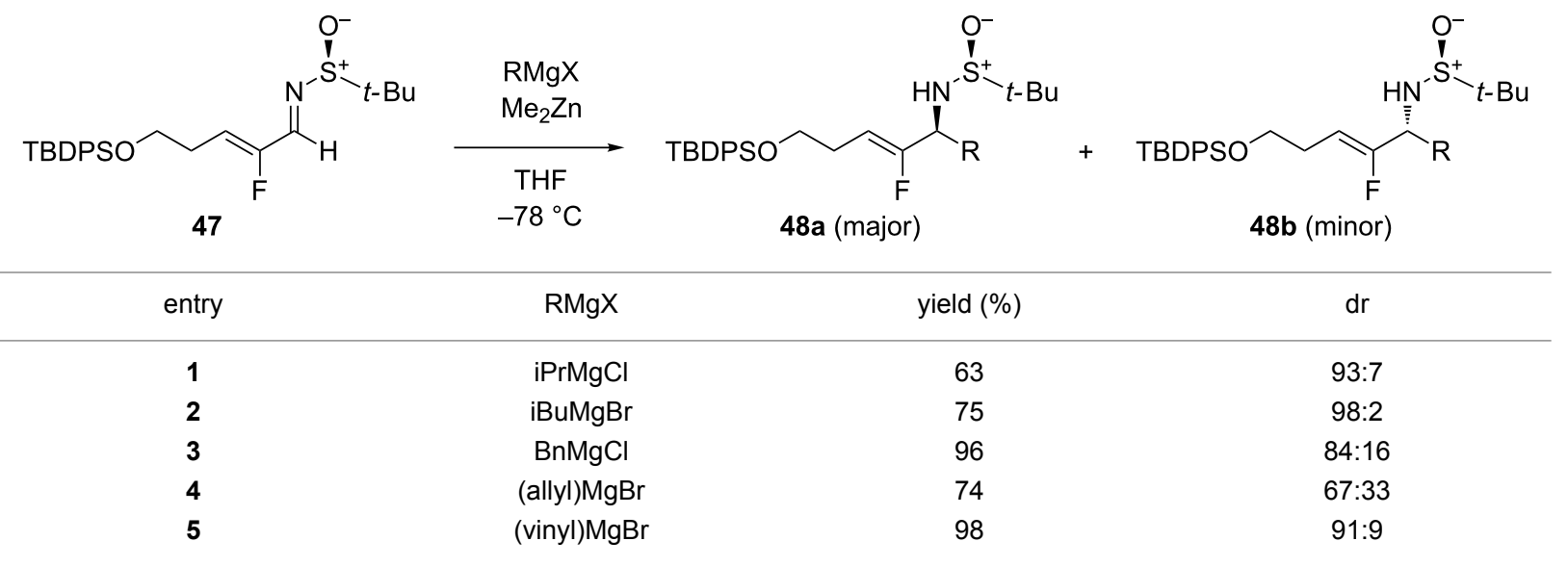

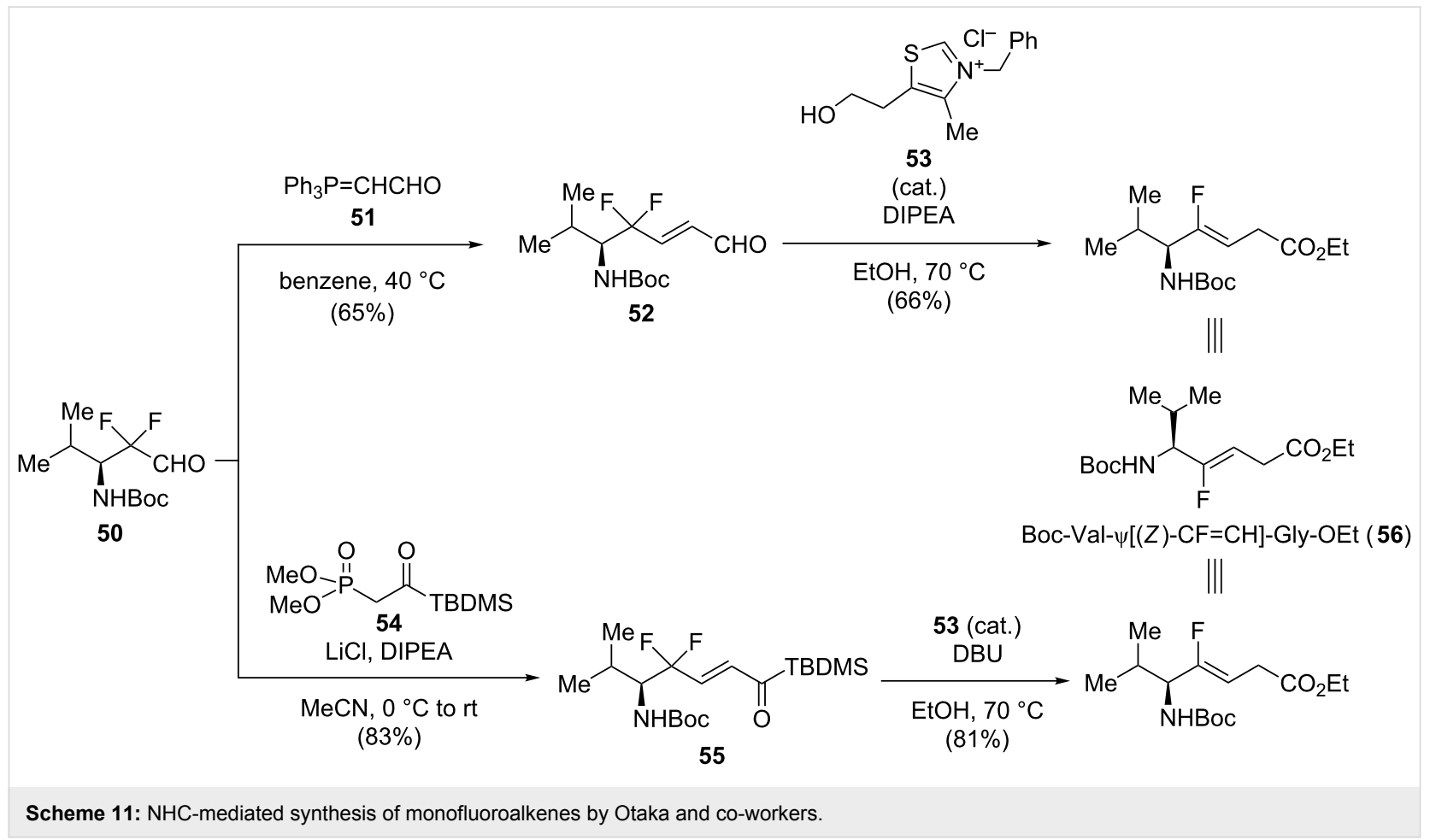

First, Reformatsky-Honda reaction of TIPS-protected phenylacetaldehyde $\mathbf{5 7}$ with the chiral auxiliary $(L)$-phenylglycine derivative $\mathbf{5 8}$ afforded 59. Removal of the chiral auxiliary and subsequent Boc protection were then performed. Reduction of the ester followed by HWE olefination of the resulting aldehyde gave the 3,3-difluoropropene $\mathbf{6 0}$. The latter was reduced in the presence of $\mathrm{SmI}_{2}$ to furnish the $(Z)$-monofluoroalkene with good yield. A final saponification gave the monofluoroalkenebased dipeptide isostere $\mathbf{6 1 .}$

Finally, Fürstner's group developed the silver-mediated fluorination of functionalized alkenylstannanes to access monofluoro- alkenes [42]. Hydrostannation of the N-protected ynamines 62 followed by electrophilic fluorination with Selectfluor gave the corresponding (Z)-monofluoroalkenes 64 in good yields (Table 2). The reported results showed that the methodology was suitable to replace an amide bond and could be used in latestage fluorination to access monofluoroalkene-based dipeptide isosteres.

\section{Xaa- $\psi[\mathrm{CF}=\mathrm{CH}]-\mathrm{Xaa}$}

The preparation of Xaa- $\psi[\mathrm{CF}-\mathrm{CH}]-\mathrm{Xaa}$ derivatives represents a synthetic challenge, as the stereochemistry of two side chains should be controlled during the synthesis. Here, the mono- 


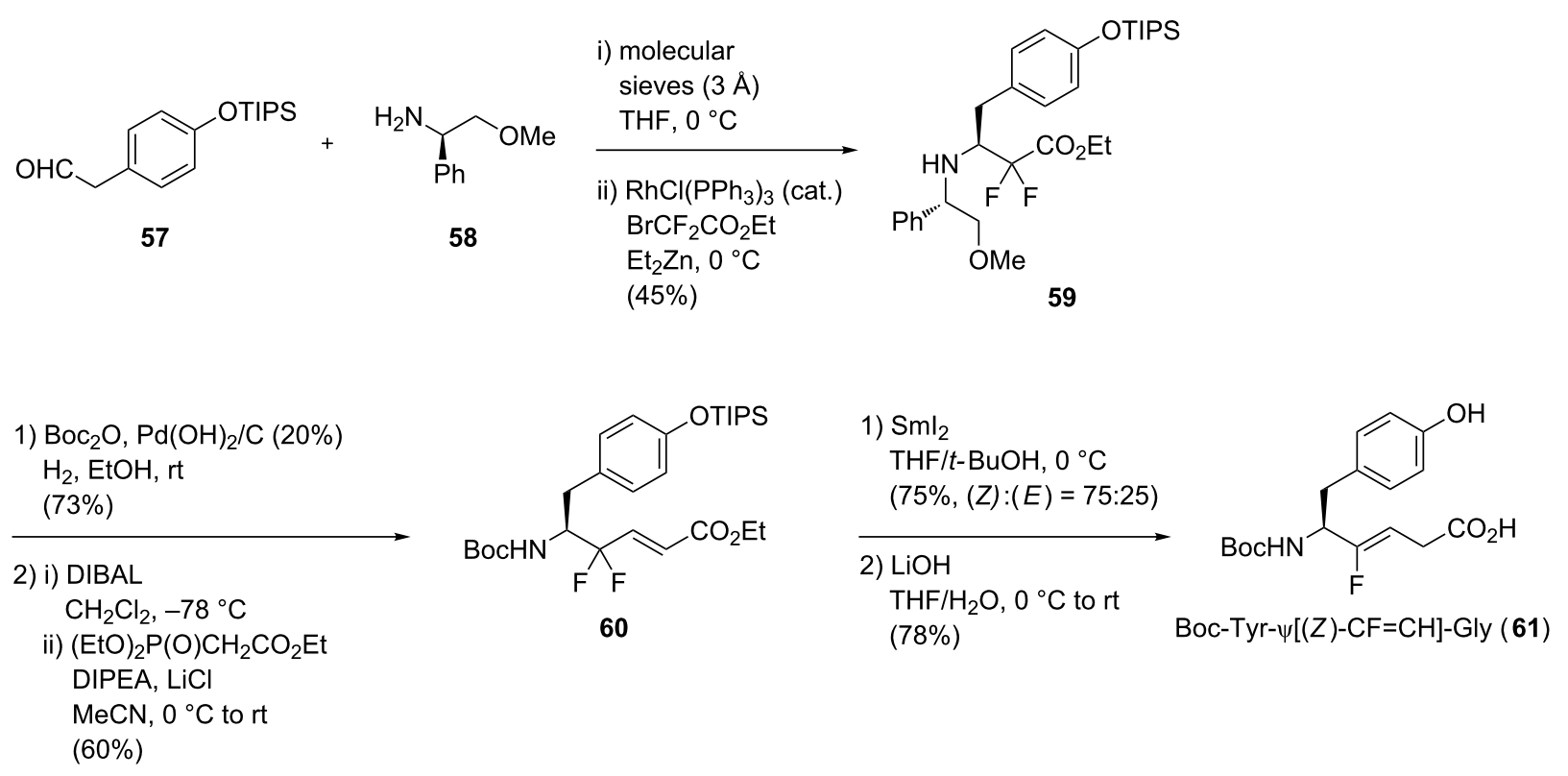

Scheme 12: Stereoselective synthesis of Boc-Tyr- $\Psi[(Z)-C F=C H]-G l y$ by Altman and co-workers.

Table 2: Silver-mediated fluorination of functionalized alkenylstannanes.

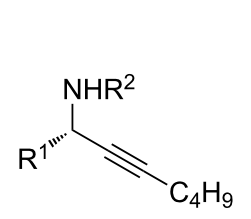

62 step 1

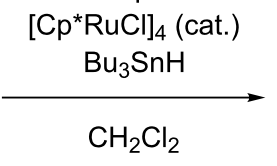

$\mathrm{CH}_{2} \mathrm{Cl}_{2}$

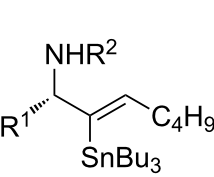

63 step 2

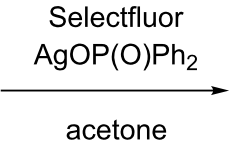

$\mathrm{F}_{\mathrm{F}}^{\mathrm{C}_{4} \mathrm{H}_{9}}$

64

\begin{tabular}{|c|c|c|c|}
\hline entry & $\mathrm{R}^{1}$ & $\mathrm{R}^{2}$ & yield (step 2, \%) \\
\hline 1 & $\mathrm{iBu}$ & $\mathrm{Cbz}$ & 77 \\
\hline 2 & $\mathrm{iBu}$ & $\mathrm{P}(\mathrm{O})(\mathrm{OPh})_{2}$ & 84 \\
\hline 3 & $\mathrm{iBu}$ & $t-\mathrm{BuSO}_{2}$ & 81 \\
\hline 4 & $\mathrm{iBu}$ & Ns & 54 \\
\hline 5 & $\mathrm{iPr}$ & $\mathrm{Cbz}$ & 76 \\
\hline 6 & $\mathrm{Ph}$ & $t-\mathrm{BuSO}_{2}$ & 76 \\
\hline 7 & $\mathrm{Ph}$ & & 83 \\
\hline
\end{tabular}

fluoroalkenes can be access either by an olefination reaction or a $\mathrm{S}_{\mathrm{N}} 2$ ' reaction starting from 3,3-difluoropropenes. First, Miller reported the asymmetric synthesis of a monofluoroalkene using a chiral auxiliary (Scheme 13) [43]. The synthesis started with the alcohol protection of known compound $\mathbf{6 5}$ followed by chiral auxiliary removal and acylation of the resulting carboxylic acid. A HWE olefination was performed in two steps on 66 to give the (Z)-monofluoroalkene 67 as a single isomer $(d r>95: 5)$. Conversion of the ester into the corresponding Weinreb amide, followed by addition of an organolithium reagent gave the corresponding ketone 69. Four further steps gave the ring skeleton for the proline residue of 71, i.e., formation of the chiral sulfinylimine, reduction into the corresponding sulfinylamine using DIBAL, deprotection of the terminal 


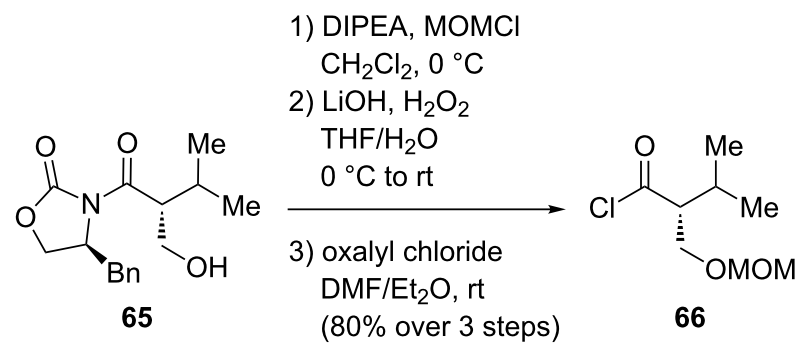

\begin{tabular}{l} 
1) $\mathrm{iPrMgCl}$ \\
$\mathrm{Me}(\mathrm{MeO}) \mathrm{NH} \cdot \mathrm{HCl}$ \\
$\mathrm{THF}, 0^{\circ} \mathrm{C}$ \\
$(79 \%)$ \\
\hline
\end{tabular}
$\mathrm{Et}_{2} \mathrm{O},-78^{\circ} \mathrm{C}$ (59\%)

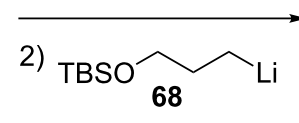<smiles>COC[C@@H](/C=C(\F)C(=O)CCCOC(C)(C)C)C(C)C</smiles>

69
1) i) $1, \mathrm{NaH}, \mathrm{THF}, \mathrm{rt}$ ii) then $66,-40^{\circ} \mathrm{C}$

2) $\mathrm{NaBH}_{4}$

$\mathrm{Et}_{2} \mathrm{O},-40{ }^{\circ} \mathrm{C}$

(69\% over 2 steps, $\mathrm{dr}>95: 5)$<smiles>CCOC(=O)/C(F)=C/[C@H](COC)C(C)C</smiles>

67<smiles>COC[C@H](/C=C(\F)C(CCCO)NS(=O)C(C)(C)C)C(C)C</smiles>

2) DIBAL, $-78^{\circ} \mathrm{C}$

(95\% over 3 steps)

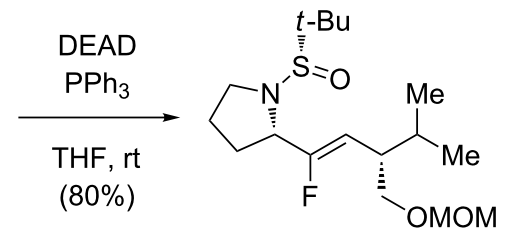

71
1) $\mathrm{HCl} /$ dioxane, $\mathrm{MeOH}, \mathrm{rt}$

2) Boc-Asp(OBn)-OH $\mathrm{EDC}, \mathrm{HOBt}, \mathrm{Et}_{3} \mathrm{~N}$ $\mathrm{CH}_{2} \mathrm{Cl}_{2}$, rt $(47 \%)$<smiles>CC(C)C(/C=C(\F)C1CCCN1C(=O)C(CC(=O)OCc1ccccc1)NC(=O)O)CO</smiles>

BocHN Boc-Asp(OBn)-Pro- $\psi[(\mathrm{Z})-\mathrm{CF}=\mathrm{CH}]-\mathrm{Val}-\mathrm{CH}_{2} \mathrm{OH}(72)$ alcohol and Mitsunobu ring closure into the corresponding pyrrolidine derivative. Then, simultaneous deprotection of the amine and the alcohol in acidic conditions followed by coupling with Boc-Asp(OBn)-OH gave the final tripeptide isostere Boc-Asp(OBn)-Pro- $\psi[(Z)-\mathrm{CF}=\mathrm{CH})-\mathrm{Val}-\mathrm{CH}_{2} \mathrm{OH}$ (72).

In the last years, Taguchi and co-workers described the synthesis of the monofluoroalkenes $\mathbf{7 4}$ by $\mathrm{S}_{\mathrm{N}} 2$ ' reaction between 4,4difluoro-5-hydroxyallylic alcohols $\mathbf{7 3}$ and Gilman reagent prepared in situ from trialkylaluminium reagents and $\mathrm{CuLi}$ (Scheme 14A) $[44,45]$. Even if the diastereoselectivity of the reaction was excellent, two problems remained. First, an excess of trialkylaluminium reagent and of copper had to be used. Second, trialkylaluminium reagents are not widely available. As an alternative, they proposed in 2011 a new synthetic route using Grignard reagents, which are widely available or can be easily synthetized in the laboratory (Scheme 14B) [46]. Unfortunately, these reagents did not react with the 4,4-difluoro-5hydroxyallylic alcohols 73. Terminal 3,3-difluoropropenes $\mathbf{7 6}$ were then prepared starting from the commercially available protected chiral hydroxyl ester 75. Reduction to the aldehyde followed by coupling with bromodifluoropropene gave two diastereoisomers $\mathbf{7 6 a}$ and $\mathbf{7 6 b}$ separable by flash chromatography. Then, the copper-catalyzed defluorinative allylic alkylation using Grignard reagents was performed on 76a and monofluoroalkenes $\mathbf{7 7}$ were obtained in good yields and high selectivity. Claisen rearrangement and further modifications (hydrolysis of the trichloroacetoamide, Boc protection of the free 
A

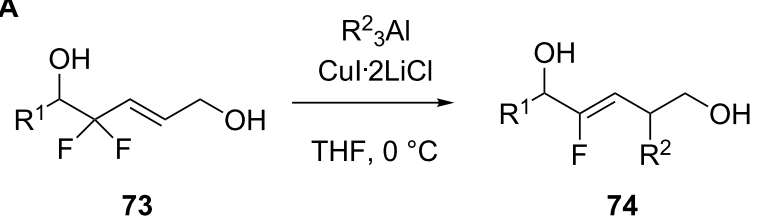

B 1 1) DIBAL,

toluene, $-78^{\circ} \mathrm{C}$

$(89 \%)$<smiles></smiles>

75

2) DMP $\mathrm{CH}_{2} \mathrm{Cl}_{2}$, rt

3) $\mathrm{BrCF}_{2} \mathrm{CH}=\mathrm{CH}_{2}$ In, DMF, rt ( $84 \%$ over 2 steps,<smiles>[R5][OH+]C[C@@H](C)[C@H](O)C(F)(F)C=C</smiles>

$76 a$<smiles></smiles>

$76 b$ $\mathrm{dr}=62: 38)$

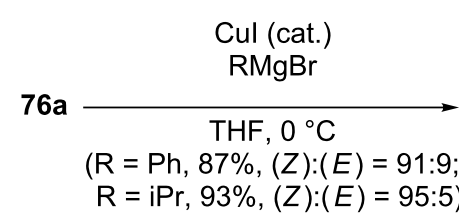

$\mathrm{R}=\mathrm{iPr}, 93 \%,(Z):(E)=95.5)$
1) $\mathrm{CCl}_{3} \mathrm{CN}, \mathrm{DBU}$ $\mathrm{CH}_{2} \mathrm{Cl}_{2}$, rt

$(\mathrm{R}=\mathrm{Ph}, 82 \%$; $\mathrm{R}=\mathrm{iPr}, 84 \%$ )

2) xylenes, $\Delta$ ( $\mathrm{R}=\mathrm{Ph}, 87 \%$; $\mathrm{R}=\mathrm{iPr}, 86 \%$ )<smiles></smiles>

78<smiles>[R]C[C@@H](NC(=O)OCc1ccccc1)C(=O)O</smiles><smiles>[R]CC(NC(=O)OCc1ccccc1)/C(F)=C/C(=O)C(=O)O</smiles>

$\mathrm{R}=\mathrm{Ph}$

Boc-Phe- $\psi[(Z)-C F=C H]-A l a ~(79 a)$

$\mathrm{R}=\mathrm{iPr}$

Boc-Leu- $\psi[(Z)-C F=C H]-A l a ~(79 b)$

Scheme 14: Copper-catalyzed synthesis of monofluoralkenes by Taguchi and co-workers.

amine, deprotection of the alcohol and Jones oxidation to give the carboxylic acid) afforded the final dipeptide isosteres 79a and $79 b$.

The sultam Xs moiety has also been used as chiral auxiliary for the synthesis of Xaa-[CF=CH]-Xaa [37]. Otaka and co-workers developed a one-pot methodology to access amide isosteres at the $C$-terminal (Scheme 15) [47]. Cyanide-mediated reductive defluorination of $\gamma, \gamma$-difluoro- $\alpha, \beta$-enoylsilane $\mathbf{8 0}$ in the presence of 18-crown- 6 followed by addition of camphorsultam $\mathbf{8 1}$ gave the corresponding monofluoroalkene 82 . Then, $\alpha$-alkylation of the amide with either allyl bromide or benzyl bromide provided the corresponding dipeptide isosteres 83a and $\mathbf{8 3 b}$. Interestingly, different amino acids, such as $\mathrm{H}_{2} \mathrm{~N}$-Gly-OEt, $\mathrm{H}_{2} \mathrm{~N}-\mathrm{Val}-\mathrm{OMe}$ and $\mathrm{H}_{2} \mathrm{~N}-\mathrm{Pro}-\mathrm{OMe}$, could be used instead of the sultam 81 to access tripeptide isosteres in a racemic manner (not shown).

Fujii and co-workers also used the sultam Xs as a chiral auxiliary but started their synthesis with 3,3-difluoropropenes bearing a $N$-enoyl sultam moiety 84 instead. A 3-key step strategy involving a copper-mediated reduction, a transmetalation and an asymmetric alkylation was adopted for the preparation of monofluoroalkenes 85 (Scheme 16). After some synthetic modifications, Fmoc-Orn(Ns)- $\psi[(Z)-\mathrm{CF}=\mathrm{CH}]-\mathrm{Orn}(\mathrm{Ns})$ [48], FmocLys(Cbz)- $\psi[(Z)-\mathrm{CF}=\mathrm{CH}]-\mathrm{Lys}(\mathrm{Cbz})[49]$ and Fmoc-Orn(Ns)$\psi[(Z)-\mathrm{CF}=\mathrm{CH}]-\mathrm{Nal}$ were obtained $[50]$.

Fujii and co-workers also worked on the stereoselective synthesis of (E)-monofluoroalkenes (Scheme 17) [51]. To obtain a 


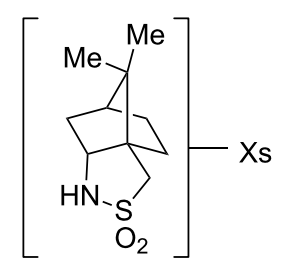

81
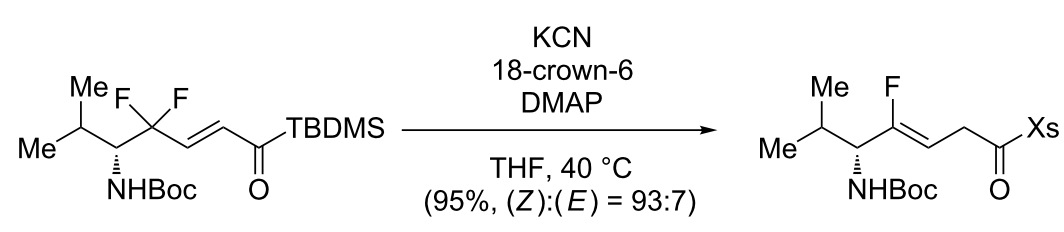

80

82

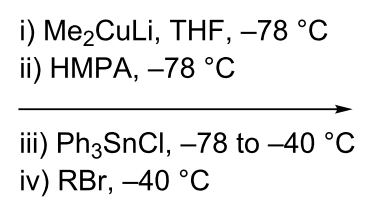<smiles>[Y9]C(=O)C([R])C=C(F)[C@@H](NC(=O)OC(C)(C)C)C(C)C</smiles>

83a

$\mathrm{R}=$ allyl $(84 \%$, de $>99 \%)$

83b

$R=\operatorname{Bn}(79 \%$, de $>99 \%)$

Scheme 15: One-pot intramolecular redox reaction to access amide-type isosteres by Otaka and co-workers.

Scheme 16: Copper-mediated reduction, transmetalation and asymmetric alkylation by Fujii and co-workers.

good selectivity towards the $(E)$-alkene, they relied on the copper-mediated reduction and the $\alpha$-alkylation on the $\gamma, \gamma$ difluoro- $\alpha, \beta$-unsaturated $\delta$-lactam 86. Unfortunately, the $\alpha$-alkylation provided a mixture of diastereoisomers $87 \mathbf{a}$ and 87b which was separable by flash chromatography. The dipeptide isostere $\mathbf{8 8}$ was finally obtained after the opening of the lactam $87 \mathbf{b}$ in acidic conditions and $N$-Boc protection.

\section{Xaa- $\Psi[\mathrm{CF}=\mathrm{C}]-$ Pro}

The first asymmetric synthesis of $\mathrm{Xaa}-\psi[\mathrm{CF}=\mathrm{C}]$-Pro was reported in 2012 by Chang's group with the synthesis of MeOCOVal- $\psi[(Z)-C F=C]$-Pro 93 (Scheme 18) [52]. Their synthesis started with a stereoselective aldol reaction using (L)-threonine to furnish a chiral $\beta$-hydroxy cyclopentanone 90. A HWE olefination converted 90 into (Z)-monofluoroalkene 91 without any 

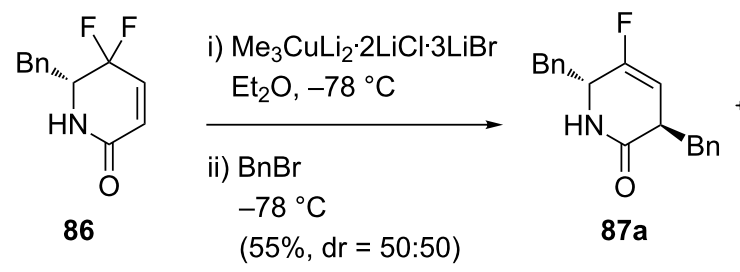<smiles>O=C1NC(Br)C(F)=CC1Br</smiles>

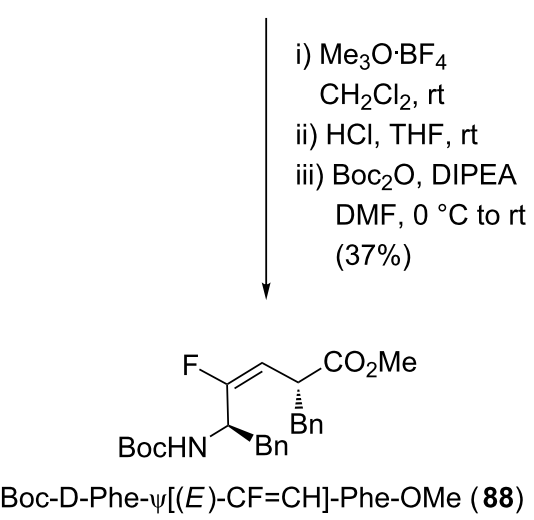

Scheme 17: Synthesis of $(E)$-monofluoroalkene-based dipeptide isostere by Fujii and co-workers.
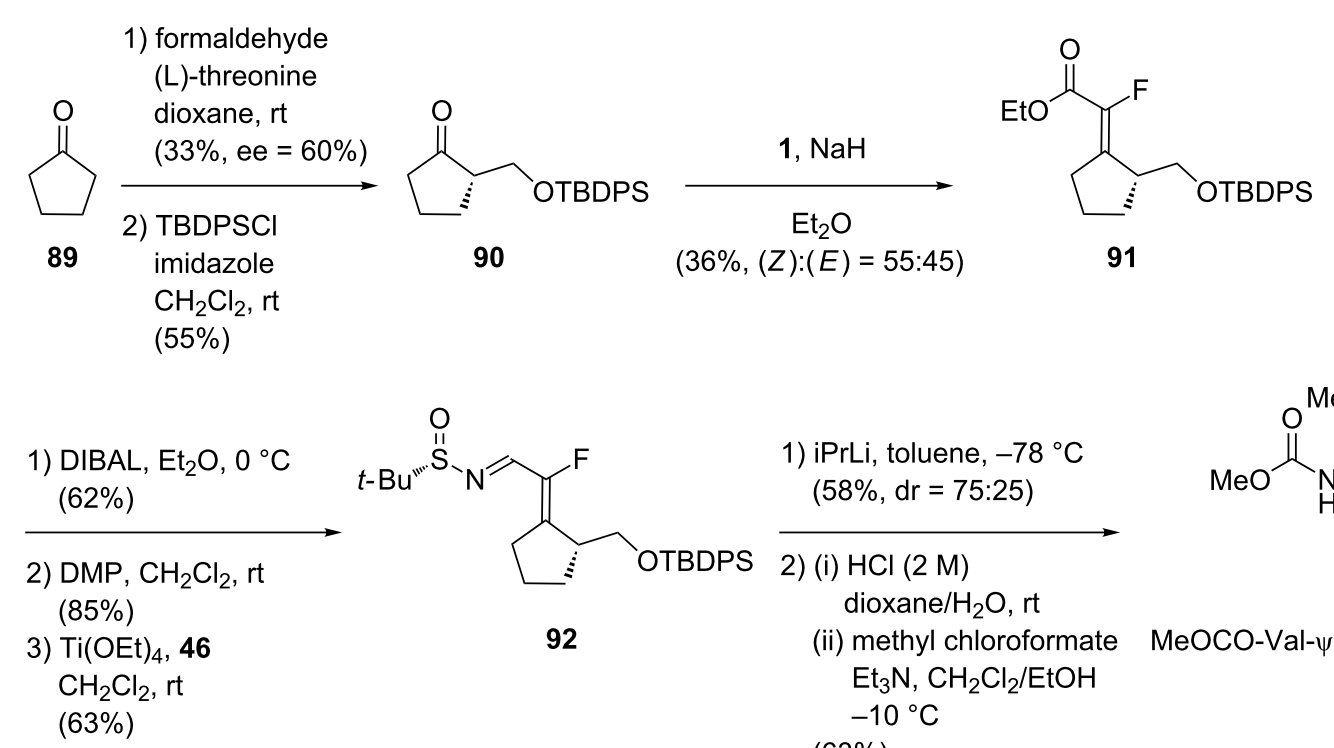

1) $\mathrm{iPrLi}$, toluene, $-78^{\circ} \mathrm{C}$ $(58 \%, d r=75: 25)$

2) (i) $\mathrm{HCl}(2 \mathrm{M})$ dioxane $/ \mathrm{H}_{2} \mathrm{O}$, rt

(ii) methyl chloroformate $\mathrm{MeOCO}-\mathrm{Val}-\psi[(Z)-\mathrm{CF}=\mathrm{C}]-$ Pro (93) $\mathrm{Et}_{3} \mathrm{~N}, \mathrm{CH}_{2} \mathrm{Cl}_{2} / \mathrm{EtOH}$ $-10{ }^{\circ} \mathrm{C}$ $(63 \%)$

3) $\mathrm{CrO}_{3}, \mathrm{H}_{2} \mathrm{SO}_{4}$ acetone, $0{ }^{\circ} \mathrm{C}$ $(61 \%)$

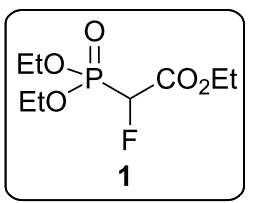


significant selectivity. The chiral Ellman's sulfinylimine 92 was obtained in 3 steps. The diastereoselective addition of isopropyllithium was then possible to afford the (L)-Leu residue with a moderate selectivity $(\mathrm{dr}=75: 25)$. Further modifications (removal of the sulfinyl group and the silyl protecting group in acidic conditions, transformation of the amine in methyl carbamate and oxidation of the primary alcohol into the corresponding carboxylic acid) gave the final isostere $\mathbf{9 3}$.

In 2013, Pannecoucke and co-workers proposed a new strategy based on a chemoenzymatic reduction of ethyl 2-oxocyclopentanecarboxylate (94) using Baker's yeast to afford the corresponding chiral alcohol 95 (Scheme 19) [53]. Then, reduction of the ester into the primary alcohol, its selective protection by a silyl protecting group, oxidation of the secondary alcohol with pyridinium dichromate into the corresponding cyclopentanone derivative and subsequent olefination using $\mathrm{CBr}_{3} \mathrm{~F}$ gave the monofluoroalkene 96 with a modest selectivity towards the $(Z)$-alkene. A Negishi coupling then gave alkene 98. Stereoselective reductive amination using a chiral sulfonamide as chiral auxiliary afforded 99 (de $>98: 2$ ). Finally, group manipulations, i.e., deprotection of the amine, Fmoc reprotection and oxidation gave the isostere $\mathbf{1 0 0}$.

Then, Pannecoucke's group proposed a modified and more versatile approach where the monofluoroalkene 102 was synthesized by a HWE olefination of the chiral cyclopentanone 101 (Scheme 20) [54]. The resulting ester was converted into the
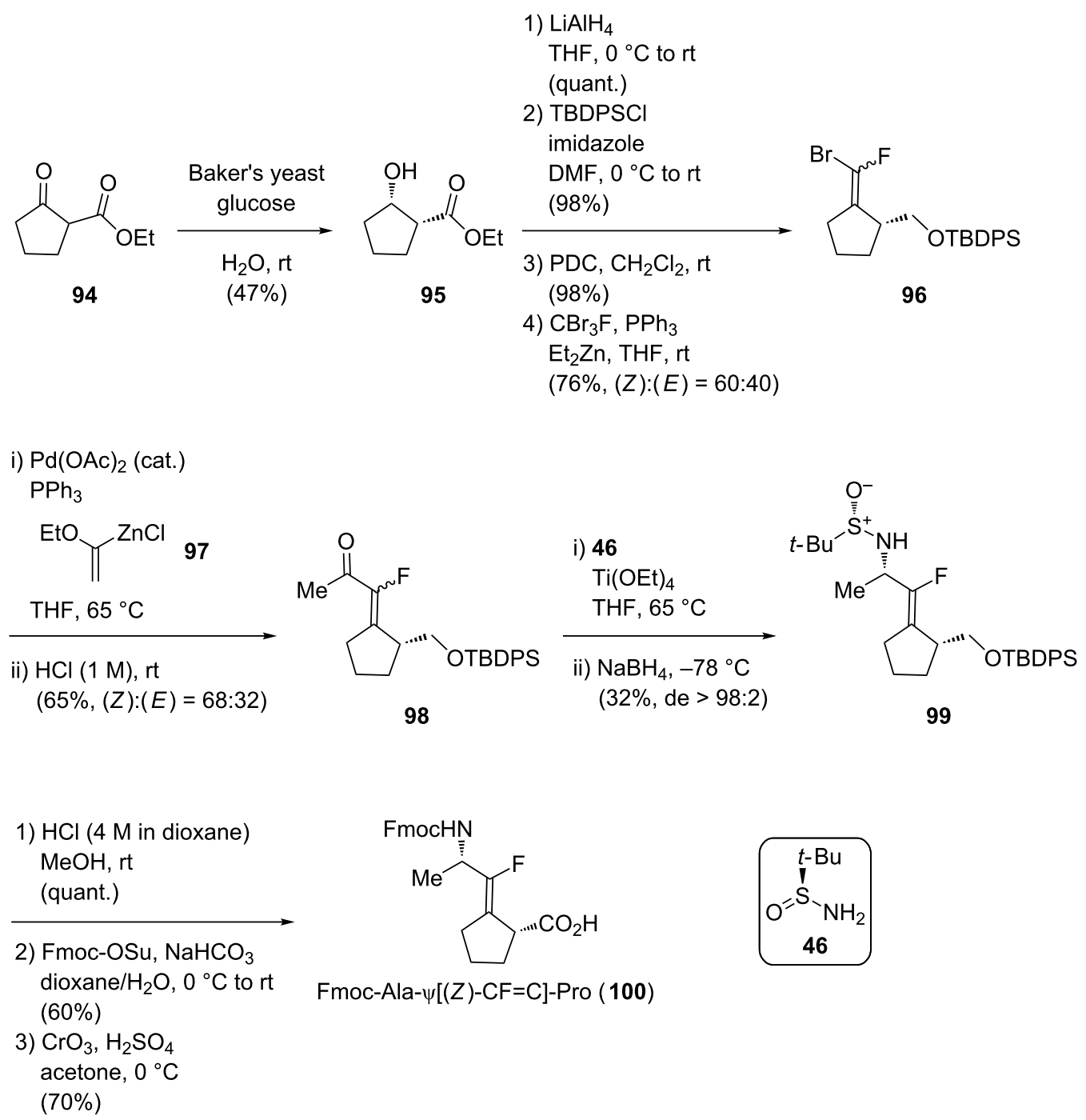

Fmoc-Ala- $\psi[(Z)-C F=C]-P r o ~(100)$ 


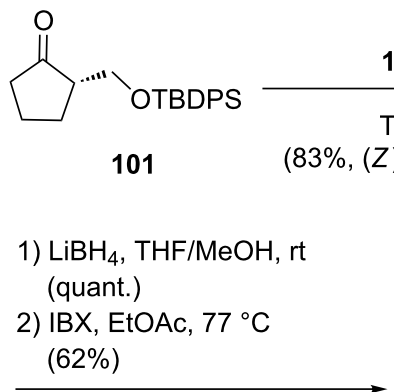

3) $t$ - $\mathrm{Bu}$ $\mathrm{O}=\bar{S}_{-\mathrm{NH}_{2}}$ $\mathrm{Ti}(\mathrm{OEt})_{4}, \mathrm{THF}, 65^{\circ} \mathrm{C}$ $(65 \%)$<smiles>CCOC(=O)C(F)=C1CCC[C@H]1CO[SbH2]</smiles>

102a<smiles>CCOC(F)=C1CCC[C@H]1CO[SbH2]</smiles>

$102 b$

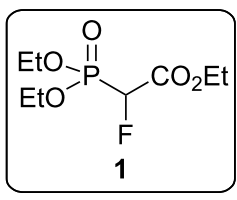

Fmoc-Val- $\psi[(Z)-C F=C]-P r o ~(106 b)$<smiles>CCOC=CC(F)=C1CCC[C@@H]1CO[SbH2+]C(C)C</smiles>

104a

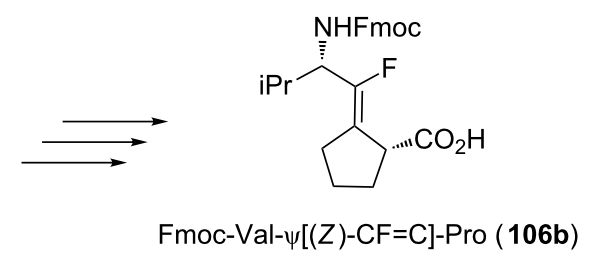

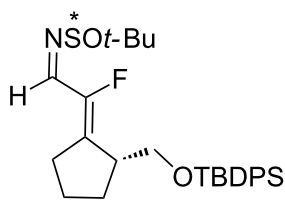

$104 b$
iPrMgCl, $\mathrm{Me}_{2} \mathrm{Zn}$

toluene, $0{ }^{\circ} \mathrm{C}$

$(90 \%, d r=96: 4)$

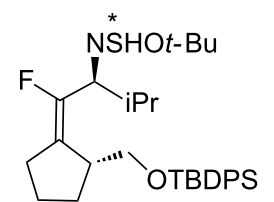

105
1) $\mathrm{HCl}(4 \mathrm{M}$ in dioxane) $\mathrm{MeOH}, \mathrm{rt}$ (quant.)

2) $\mathrm{Fmoc}-\mathrm{OSu}, \mathrm{NaHCO}_{3}$ dioxane $/ \mathrm{H}_{2} \mathrm{O}$, rt (79\%)

3) $\mathrm{CrO}_{3}, \mathrm{H}_{2} \mathrm{SO}_{4}$

acetone, $0{ }^{\circ} \mathrm{C}$ (51\%)

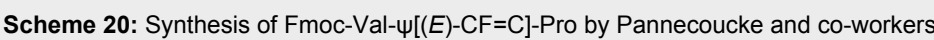

aldehyde and $\beta$-fluoroenimine 104 was obtained using Ellman's conditions. At this stage, the lateral chain of the N-terminal residue was added by an alkylation reaction using a Grignard reagent to give $\mathbf{1 0 5}$. The last three steps (simultaneous deprotection of the amine and the alcohol in acidic conditions, Fmoc protection of the amine and oxidation of the alcohol into the corresponding carboxylic acid) led to the formation of three isosteres: Fmoc-Val- $\psi[(E)-\mathrm{CF}=\mathrm{C}]-$ Pro (106a), Fmoc-Val- $\psi[(Z)-$ $\mathrm{CF}=\mathrm{C}]-$ Pro (106b) and Fmoc-Ala- $\psi[(Z)-\mathrm{CF}=\mathrm{C}]-$ Pro.

\section{Applications}

In this section, recent applications of monofluoroalkene-based dipeptide isosteres will be briefly described.

Chang's group used the Val- $\psi[(Z)-\mathrm{CF}=\mathrm{C}]$-Pro isostere (see Scheme 18) to synthesize a fluorinated analogue of BMS790052, which is a promising inhibitor of the non-structural protein NS5A, an interesting target of the chronic hepatitis C virus [52]. The monofluoroalkene replaced the amide group, and the use of a dipeptide isostere containing a proline residue favoured a $\gamma$-turn substructure which is necessary for the inter- action with the NS5A protein. This fluorinated peptide isostere showed activity in the picomolar range against one genotype and did not exhibit any cytotoxicity (Figure 4).

Pannecoucke and co-workers synthesized three heptapeptides, Gly-Gly- $\psi[(Z)-\mathrm{CF}=\mathrm{CH}]$-Phe-Ser-Phe-Arg-Phe-NH ${ }_{2}$, Gly- $\psi[(Z)-$ $\mathrm{CF}=\mathrm{CH}]-\mathrm{Gly}-\mathrm{Phe}-\mathrm{Ser}-\mathrm{Phe}-\mathrm{Arg}-\mathrm{Phe}-\mathrm{NH}_{2}$ and $\mathrm{Gly}-\psi[(E)-$ $\mathrm{CF}=\mathrm{CH}]$-Gly-Phe-Ser-Phe-Arg-Phe- $\mathrm{NH}_{2}$ (see Scheme 7), representing the seven last amino acids of the neuropeptide 26 Fra [34]. For the analogue containing the Gly- $\psi[(Z)-$ $\mathrm{CF}=\mathrm{CH}]$-Phe isostere, epimerization was observed during last stages of the synthesis. The two diastereoisomers were separated after incorporation into the heptapeptide prior to biological studies, hence one had a D-Phe while the other had a L-Phe. The functional activity of the fluorinated mutants was evaluated by the calcium mobilizing response in GPR103-transfected cells. The peptides containing Gly- $\psi[(Z)-\mathrm{CF}=\mathrm{CH}]-\mathrm{Gly}$ or Gly- $\psi[(E)-\mathrm{CF}=\mathrm{CH}]$-Gly showed a higher activity than the nonfluorinated one, while an important decrease was observed for the peptides containing Gly- $\psi[(Z)-\mathrm{CF}=\mathrm{CH}]-\mathrm{D}-\mathrm{Phe}$ and Gly$\psi[(Z)-\mathrm{CF}=\mathrm{CH}]-\mathrm{L}-\mathrm{Phe}$ (Table 3 ). These results underlined the 


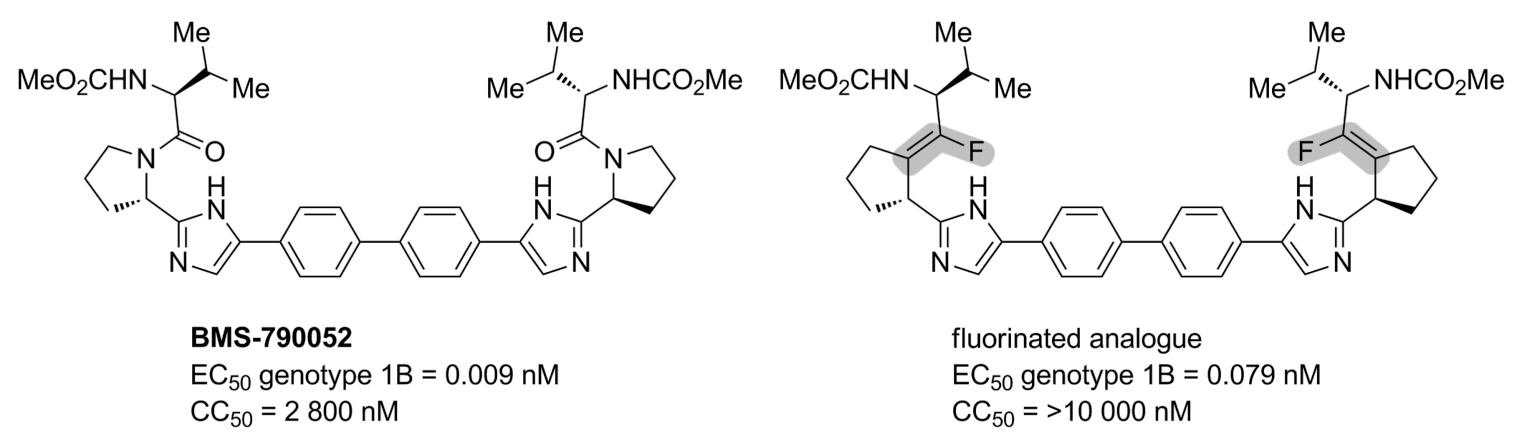

Figure 4: BMS-790052 and its fluorinated analogue.

Table 3: Activity towards the calcium mobilizing response in GPR103-transfected cells of different 26FRa analogues.

$\begin{array}{lll}\text { entry } & \text { pseudopeptides } & \mathrm{EC}_{50}(\mathrm{nM})\end{array}$

\begin{tabular}{crc}
\hline 1 & Gly-Gly-Phe-Ser-Phe-Arg-Phe-NH$H_{2}$ & $(739 \pm 149)$ \\
2 & Gly- $\Psi[(Z)-C F=C H]-G l y-P h e-S e r-P h e-A r g-P h e-N_{2}$ & $(618 \pm 104)$ \\
3 & Gly- $\Psi[(E)-C F=C H]-G l y-P h e-S e r-P h e-A r g-P h e-N_{2}$ & $(538 \pm 13)$ \\
4 & Gly-Gly- $\Psi[(Z)-C F=C H]-D-P h e-S e r-P h e-A r g-P h e-N_{2}$ & 6752 \\
5 & Gly-Gly- $\Psi[(Z)-C F=C H]-L-P h e-S e r-P h e-A r g-P h e-N_{2}$ &
\end{tabular}

importance of the Gly-Phe amide bond for the functional activity of the peptide. On the other hand, the fluorinated peptides showed a higher stability towards enzymatic degradation.

Fujii's group studied several applications of monofluoroalkenebased dipeptide isosteres. First, the affinity of the monofluoroalkene-based dipeptide isosteres Phe- $\psi[(Z)-\mathrm{CF}=\mathrm{CH}]-\mathrm{Gly}$ and Phe- $\psi[(E)-\mathrm{CF}=\mathrm{CH}]$-Gly for the peptide transporter PEPT1 was investigated (see Scheme 17) [51]. As the (Z)-monofluoroalkenes had a better bioactivity than the $(E)$, the conclusion was that the transporter preferred the s-trans peptide bond. The $K_{\mathrm{i}}$ values obtained were also compared to the alkene analogues (Table 4).

Comparison between Phe- $\psi[(Z)-\mathrm{CF}=\mathrm{CH}]-\mathrm{Gly}$ and Phe- $\psi[(E)-$ $\mathrm{CF}=\mathrm{CH}]$-Gly isosteres and their alkene analogues was also performed in an antagonist activity study towards GPR54. The fluorinated isosteres were incorporated into pentapeptides using Fmoc solid phase peptide synthesis (SPPS). Similar results as above were obtained in the sense that the activity of the s-trans peptide bond isostere was superior and that the fluorinated pseudopeptides were not more active than the natural peptide or the alkene-containing pseudopeptides (Figure 5) [55].

Fujii and co-workers also prepared, without isomerization or epimerization, cyclic pseudopeptides using Fmoc SPPS [48,50].
Biological studies were conducted on monofluoroalkene-containing analogues of $\mathrm{FC131}$, which is a known antagonist of the chemokine receptor CXCR4. The latter has implications in cancer metastasis and HIV 1 infection. Anti-HIV 1 activity of the fluorinated antagonists showed an acceptable $\mathrm{EC}_{50}$ for the mutant containing $\operatorname{Arg}-\psi[(Z)-\mathrm{CF}=\mathrm{CH}]-\mathrm{Arg}$, while the one containing $\operatorname{Arg}-\psi[(Z)-\mathrm{CF}=\mathrm{CH}]-\mathrm{Nal}$ (where $\mathrm{NaI}=\mathrm{L}-3$-(2-naphthyl)alanine) was not active (Table 5).

Finally, incorporation at different positions of the monofluoroalkene-based dipeptide isostere Lys- $\psi[(Z)-\mathrm{CF}=\mathrm{CH}]$-Lys into a fusion inhibitory peptide active against HIV 1, SC29EK, was investigated [49]. Weak to moderate anti-HIV activity was observed for the fluorinated analogues, but the potency was always lower than for SC29EK. This suggested than the H-bonding behaviour was important for the activity (Table 6). Conformational studies of the fluorinated peptide using circular dichroism also showed that the incorporation of the monofluoroalkene did not perturb the formation of the secondary structure of the peptide, which was a $\alpha$-helix.

Dory and co-workers wanted to study the pentapeptide Leuenkephaline, which can have analgesic properties when bounded to the DOPr receptor [36]. In order to study some derivative of the peptide, Fmoc-Gly- $\psi[(Z-\mathrm{CF}=\mathrm{CH}]-\mathrm{Phe}$ was synthesized (see Scheme 9). Using Fmoc SPPS, the fluorinated 
Table 4: $K_{\mathrm{i}}$ values of Phe-Gly and analogues based on inhibition of $\left[{ }^{3} \mathrm{H}\right] \mathrm{Gly}$-Sar uptake by PEPT1 in Caco-2 cells.

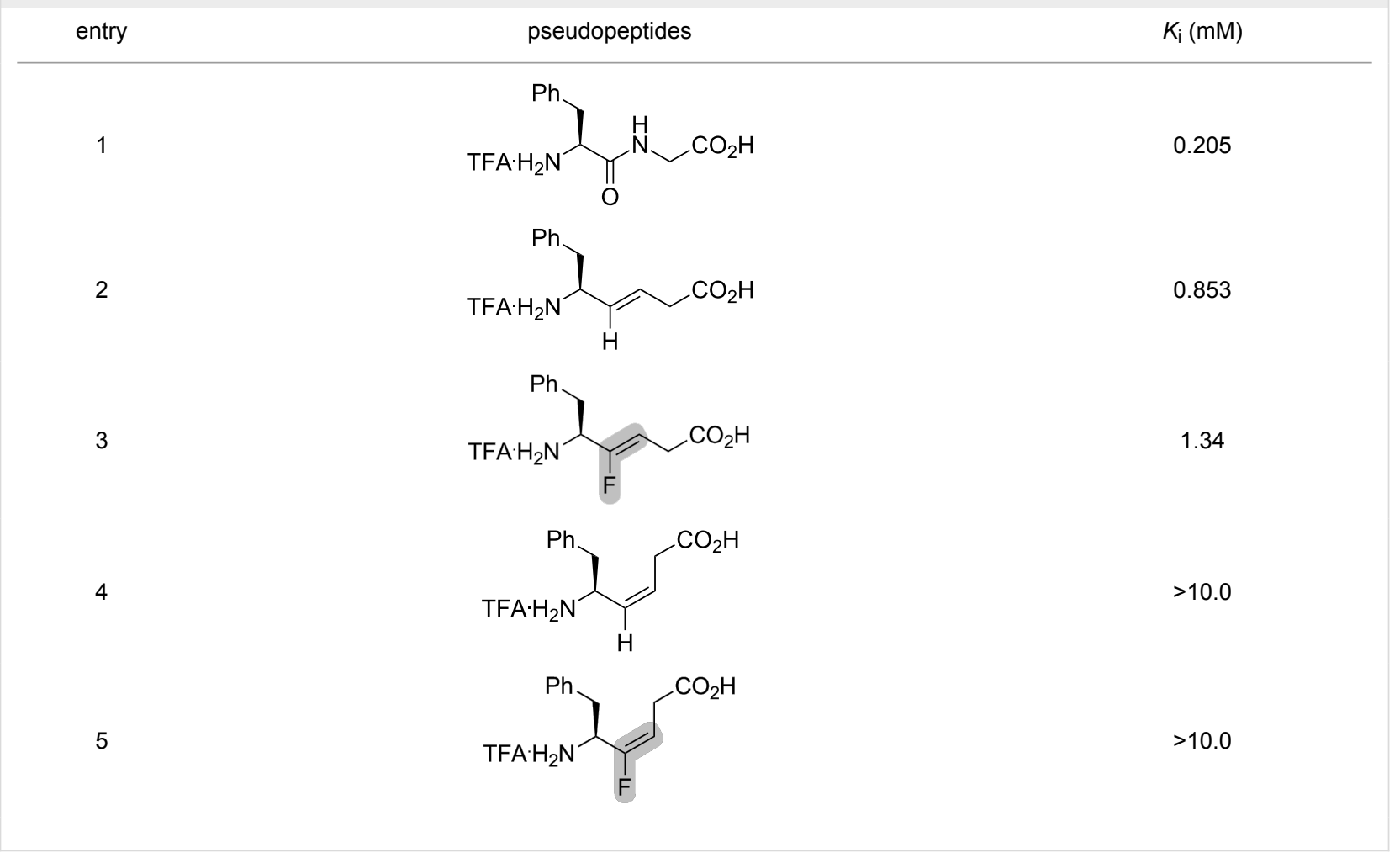<smiles>CC(C)C[C@H](NC(=O)Cc1ccc(C(CC(=O)c2ccc(CN)cc2)Cc2ccccc2)cc1)C(=O)N[C@@H](CCCNC(=N)N)C(=O)N[C@@H](Cc1c[nH]c2ccccc12)C(N)=O</smiles>

Figure 5: Bioactivities of pentapeptide analogues based on the relative maximum agonistic activity at $10 \mathrm{nM}$ of the compound to $1 \mu \mathrm{M}$ kisspeptin-10 (\%). 100\% = maximum agonistic activity at $1 \mu \mathrm{m}$ kisspeptin-10.

mutant was incorporated in the sequence of the Leu-enkephaline to obtain Tyr-Gly-Gly- $\psi[(Z)-\mathrm{CF}=\mathrm{CH}]-\mathrm{Phe}-\mathrm{Leu}$. The fluorinated Leu-enkephaline presented a 6 -fold decreased binding affinity towards the DOPr receptor that the non-fluorinated analogue, showing that a hydrogen bond acceptor is necessary at this position of the peptide (Figure 6). The fluorinated peptide also showed higher lipophilicity, which can improve its pharmacokinetic properties.
Altman and co-workers also studied a fluorinated mutant of the Leu-enkephaline [41]. The isostere Boc-Tyr- $\psi[(Z)-\mathrm{CF}=\mathrm{CH}]-$ Gly (see Scheme 12) was coupled to a tripeptide to afford BocTyr- $\psi[(Z)-C F=C H]-G l y-G l y-P h e-L e u$. Then, the opioid activity was calculated towards the DOPr receptor and an $\mathrm{EC}_{50}$ in the nanomolar range was observed (Figure 7). Even if this value represented a 60 -fold decrease compared to the non-fluorinated peptide, it showed that the fluorinated peptide binds to the re- 
Table 5: Anti-HIV activities of FC131 and its fluorinated derivatives against three HIV strains.

entry pseudopeptides

$\operatorname{EC50}(\mu \mathrm{M})$

NL4-3 IIIB

Ba-L<smiles></smiles>

$(0.014 \pm 0.002) \quad(0.019 \pm 0.003) \quad>10$

2<smiles>C=C=C(NC(=O)[C@H](Cc1ccc(O)cc1)NC(=O)CNC(=O)[C@H](Cc1ccc2ccccc2c1)NC(=O)CCCNC(=N)N)[C@@H](C=C(F)F)CCCNC(=N)N</smiles>

$(0.332 \pm 0.073)$

$(0.403 \pm 0.051)$

$>10$<smiles>N=C(N)NCCCNC(=O)[C@H](CCCNC(=N)N)NC(=O)[C@H](Cc1ccc(O)cc1)NC(=O)CNC(=O)[C@H](Cc1ccc2ccccc2c1)NC(=O)[C@H](C=C(F)F)Cc1ccc2ccccc2c1</smiles>

$>10$

$>10$

$>10$

Table 6: Anti-HIV activities of SC29EK and its fluorinated derivatives against three HIV strains. The number indicates the position of the dipeptide isostere.

entry

pseudopeptides

EC50 (nM)
NL4-3

$(2.2 \pm 0.2)$

$(5220 \pm 202)$

$(599 \pm 96)$

$(663 \pm 242)$

$(43 \pm 7)$

IIIB

Ba-L

SC29EK-6-Lys- $\Psi[(Z)-C F=C H]-L y s$

SC29EK-13-Lys- $\psi[(Z)-C F=C H]-L y s$

SC29EK-20-Lys- $\Psi[(Z)-C F=C H]-L y s$

SC29EK-27-Lys- $\psi[(Z)-C F=C H]-L y s$
$(6.5 \pm 0.9)$

$>10000$

(3010 \pm 554$)$

$(2200 \pm 712)$

$(237 \pm 16)$
$(1.9 \pm 0.2)$

$(5580 \pm 1920)$

$(600 \pm 302)$

(527 \pm 95$)$

$(51 \pm 7)$ 
<smiles>CC(C)CC(NC(=O)C(Cc1ccccc1)NC(=O)CNC(=O)CNC(=O)C(N)Cc1ccc(O)cc1)C(=O)[O-]</smiles>

Leu-enkephalin

$K_{\mathrm{i}}=(6.9 \pm 2.3) \mathrm{nM}$
$\mathrm{HO}$<smiles>Cc1ccc(C[C@@H](N)C(=O)NCC(=O)NC/C(F)=C/C(Cc2ccccc2)C(=O)NC(CC(C)C)C(=O)[O-])cc1</smiles>

fluorinated Leu-enkephalin $K_{\mathrm{i}}=(43 \pm 14) \mathrm{nM}$

Figure 6: Structures and affinities of the Leu-enkephalin and its fluorinated analogue. The affinity towards DOPr was measured by competitive binding assays.<smiles>CC(C)CC(NC(=O)C(Cc1ccccc1)NC(=O)CNC(=O)CNC(=O)C(N)Cc1ccc(O)cc1)C(=O)[O-]</smiles>

Leu-enkephalin

$\mathrm{EC}_{50}=(0.08 \pm 0.01) \mathrm{nM}$<smiles>CC(=O)CC(NC(=O)C(Cc1ccccc1)NC(=O)CNC(=O)CC=C(F)C(N)Cc1ccc(O)cc1)C(=O)[O-]</smiles>

fluorinated Leu-enkephalin $\mathrm{EC}_{50}=(5 \pm 2) \mathrm{nM}$

Figure 7: Activation of the opioid receptor DOPr by Leu-enkephaline and a fluorinated analogue.

ceptor and that the amide bond at this position was not necessary. Thus, Boc-Tyr- $\psi[(Z)-\mathrm{CF}=\mathrm{CH}]-\mathrm{Gly}-\mathrm{Gly}-\mathrm{Phe}-\mathrm{Leu}$ is shown to be a better isostere than Tyr-Gly-Gly- $\psi[(Z)-C F=C H]-P h e-$ Leu for interactions with the DOPr receptor. The activity was also tested for the MOPr receptor, where it was lower than the Leu-enkephaline, and no activity was shown for the KOPr receptor.

\section{Conclusion}

Different methodologies to synthesize monofluoroalkene-based dipeptide isosteres were developed since 2007. First, synthetic approaches to analogues in which there is no side chain or where the side chain stereochemistry is not controlled was discussed, either to obtain Gly- $\psi[\mathrm{CF}=\mathrm{CH}]-\mathrm{Gly}, \mathrm{Xaa}-\psi[\mathrm{CF}=\mathrm{CH}]-$ Gly or Xaa- $\psi[\mathrm{CF}=\mathrm{C}]-$ Pro. The synthesis of fluorinated isosteres with control of the stereochemistry at the side chain was then described, allowing the preparation of Gly- $\psi[\mathrm{CF}=\mathrm{CH}]-\mathrm{Xaa}$, $\mathrm{Xaa}-\psi[\mathrm{CF}=\mathrm{CH}]-\mathrm{Gly}$, Xaa- $\psi[\mathrm{CF}=\mathrm{CH}]-\mathrm{Xaa}$ and $\mathrm{Xaa}-\psi[\mathrm{CF}=\mathrm{C}]-$ Pro. In both syntheses, control of the geometry of the fluoroalkene (i.e., $Z$ vs $E$ ) was important. Finally, as the monofluoroalkene is of interest in medicinal chemistry as a non-hydrolyzable peptide bond isostere, some applications have been presented.

\section{Acknowledgements}

We acknowledge the financial support of NSERC, PROTEO and Université Laval. MD thanks NSERC for a Vanier Canada Graduate Scholarship.

\section{ORCID ${ }^{\circledR}$ iDs}

Myriam Drouin - https://orcid.org/0000-0001-6707-2357

Jean-François Paquin - https://orcid.org/0000-0003-2412-3083

\section{References}

1. Newman, D. J.; Cragg, G. M. J. Nat. Prod. 2012, 75, 311-335. doi:10.1021/np200906s

2. Craik, D. J.; Fairlie, D. P.; Liras, S.; Price, D. Chem. Biol. Drug Des. 2013, 81, 136-147. doi:10.1111/cbdd.12055

3. Vlieghe, P.; Lisowski, V.; Martinez, J.; Khrestchatisky, M. Drug Discovery Today 2010, 15, 40-56. doi:10.1016/j.drudis.2009.10.009

4. Choudhary, A.; Raines, R. T. ChemBioChem 2011, 12, 1801-1807. doi:10.1002/cbic.201100272

5. Taguchi, T.; Yanai, H. Fluorinated Moieties for Replacement of Amide and Peptide Bonds. In Fluorine in Medicinal Chemistry and Chemical Biology; Ojima, I., Ed.; Blackwell Publishing Inc., 2009; pp 257-290. doi:10.1002/9781444312096.ch10

6. Angell, Y. L.; Burgess, K. Chem. Soc. Rev. 2007, 36, 1674-1689. doi:10.1039/b701444a 
7. Wipf, P.; Henninger, T. C.; Geib, S. J. J. Org. Chem. 1998, 63, 6088-6089. doi:10.1021/j0981057v

8. Abraham, R. J.; Ellison, S. L. R.; Schonholzer, P.; Thomas, W. A Tetrahedron 1986, 42, 2101-2110. doi:10.1016/S0040-4020(01)87627-4

9. Champagne, P. A.; Desroches, J.; Paquin, J.-F. Synthesis 2015, 47, 306-322. doi:10.1055/s-0034-1379537

10. O'Hagan, D.; Rzepa, H. S. Chem. Commun. 1997, 645-652. doi:10.1039/a604140j

11. Howard, J. A. K.; Hoy, V. J.; O'Hagan, D.; Smith, T. G. Tetrahedron 1996, 52, 12613-12622. doi:10.1016/0040-4020(96)00749-1

12. Urban, J. J.; Tillman, B. G.; Cronin, W. A. J. Phys. Chem. A 2006, 110, 11120-11129. doi:10.1021/jp062881n

13. Joseph, A. P.; Srinivasan, N.; de Brevern, A. G. Amino Acids 2012, 43, 1369-1381. doi:10.1007/s00726-011-1211-9

14. Ramachandra, G. N.; Sasisekharan, V. Adv. Protein Chem. 1968, 23 , 283-437. doi:10.1016/S0065-3233(08)60402-7

15. Ramachandra, G. N.; Mitra, A. K. J. Mol. Biol. 1976, 107, 85-92. doi:10.1016/S0022-2836(76)80019-8

16. van Steenis, J. H.; van der Gen, A. J. Chem. Soc., Perkin Trans. 1 2002, 2117-2133. doi:10.1039/b106187a

17. Zajc, B.; Kumar, R. Synthesis 2010, 1822-1836. doi:10.1055/s-0029-1218789

18. Landelle, G.; Bergeron, M.; Turcotte-Savard, M.-O.; Paquin, J.-F. Chem. Soc. Rev. 2011, 40, 2867-2908. doi:10.1039/c0cs00201a

19. Yanai, H.; Taguchi, T. Eur. J. Org. Chem. 2011, 5939-5954. doi:10.1002/ejoc.201100495

20. Hara, S. Top. Curr. Chem. 2012, 327, 59-86. doi:10.1007/128_2012_317

21. Pfund, E.; Lequeux, T.; Gueyrard, D. Synthesis 2015, 47, 1534-1546. doi:10.1055/s-0034-1380548

22. Champagne, P. A.; Desroches, J.; Hamel, J.-D.; Vandamme, M.; Paquin, J.-F. Chem. Rev. 2015, 115, 9073-9174. doi:10.1021/cr500706a

23. Sano, S.; Kuroda, Y.; Saito, K.; Ose, Y.; Nagao, Y. Tetrahedron 2006, 62, 11881-11890. doi:10.1016/j.tet.2006.09.096

24. Calata, C.; Pfund, E.; Lequeux, T. J. Org. Chem. 2009, 74, 9399-9405. doi:10.1021/jo901540c

25. Calata, C.; Pfund, E.; Lequeux, T. Tetrahedron 2011, 67, 1398-1405. doi:10.1016/j.tet.2010.12.061

26. Yanai, H.; Okada, H.; Sato, A.; Okada, M.; Taguchi, T. Tetrahedron Lett. 2011, 52, 2997-3000. doi:10.1016/j.tetlet.2011.03.148

27. Sato, A.; Yanai, H.; Suzuki, D.; Okada, M.; Taguchi, T. Tetrahedron Lett. 2015, 56, 925-929. doi:10.1016/j.tetlet.2014.12.128

28. Nihei, T.; Nishi, Y.; Ikeda, N.; Yokotani, S.; Ishihara, T.; Arimitsu, S.; Konno, T. Synthesis 2016, 48, 865-881. doi:10.1055/s-0035-1560390

29. Boros, L. G.; De Corte, B.; Gimi, R. H.; Welch, J. T.; Wu, Y.; Handschumacher, R. E. Tetrahedron Lett. 1994, 35, 6033-6036. doi:10.1016/0040-4039(94)88067-0

30. Welch, J. T.; Lin, J. Tetrahedron 1996, 52, 291-304. doi:10.1016/0040-4020(95)00912-R

31. Van der Veken, P.; Kertèsz, I.; Senten, K.; Haemers, A.; Augustyns, K. Tetrahedron Lett. 2003, 44, 6231-6234. doi:10.1016/S0040-4039(03)01542-9

32. Sano, S.; Matsumoto, T.; Nakao, M. Tetrahedron Lett. 2014, 55 , 4480-4483. doi:10.1016/j.tetlet.2014.06.063

33. Sano, S.; Matsumoto, T.; Nanataki, H.; Tempaku, S.; Nakao, M. Tetrahedron Lett. 2014, 55, 6248-6251. doi:10.1016/j.tetlet.2014.09.077
34. Pierry, C.; Couve-Bonnaire, S.; Guilhaudis, L.; Neveu, C.; Marotte, A.; Lefranc, B.; Cahard, D.; Ségalas-Milazzo, I.; Leprince, J.; Pannecoucke, X. ChemBioChem 2013, 14, 1620-1633. doi:10.1002/cbic.201300325

35. Guérin, D.; Dez, I.; Gaumont, A.-C.; Pannecoucke, X.; Couve-Bonnaire, S. Org. Lett. 2016, 18, 3606-3609. doi:10.1021/acs.orglett.6b01631

36. Nadon, J.-F.; Rochon, K.; Grastilleur, S.; Langlois, G.; Hà Dao, T. T.; Blais, V.; Guérin, B.; Gendron, L.; Dory, Y. L. ACS Chem. Neurosci. 2017, 8, 40-49. doi:10.1021/acschemneuro.6b00163

37. Narumi, T.; Niida, A.; Tomita, K.; Oishi, S.; Otaka, A.; Ohno, H.; Fujii, N. Chem. Commun. 2006, 4720-4722. doi:10.1039/b608596b

38. Pierry, C.; Zoute, L.; Jubault, P.; Pfund, E.; Lequeux, T.; Cahard, D.; Couve-Bonnaire, S.; Pannecoucke, X. Tetrahedron Lett. 2009, 50, 264-266. doi:10.1016/j.tetlet.2008.10.140

39. Pierry, C.; Cahard, D.; Couve-Bonnaire, S.; Pannecoucke, X. Org. Biomol. Chem. 2011, 9, 2378-2386. doi:10.1039/c0ob00773k

40. Yamaki, Y.; Shigenaga, A.; Tomita, K.; Narumi, T.; Fujii, N.; Otaka, A. J. Org. Chem. 2009, 74, 3272-3277. doi:10.1021/jo900134k

41. Karad, S. N.; Pal, M.; Crowley, R. S.; Prisinzano, T. E.; Altman, R. A. ChemMedChem 2017, 12, 571-576. doi:10.1002/cmdc.201700103

42. Sommer, H.; Fürstner, A. Chem. - Eur. J. 2017, 23, 558-562. doi:10.1002/chem.201605444

43. Jakobsche, C. E.; Peris, G.; Miller, S. J. Angew. Chem., Int. Ed. 2008, 47, 6707-6711. doi:10.1002/anie.200802223

44. Okada, M.; Nakamura, Y.; Saito, A.; Sato, A.; Horikawa, H.; Taguchi, T. Tetrahedron Lett. 2002, 43, 5845-5847. doi:10.1016/S0040-4039(02)01169-3

45. Nakumara, Y.; Okada, M.; Sato, A.; Horikawa, H.; Koura, M.; Saito, A.; Taguchi, T. Tetrahedron 2005, 61, 5741-5753. doi:10.1016/j.tet.2005.04.034

46. Watanabe, D.; Koura, M.; Saito, A.; Yanai, H.; Nakamura, Y.; Okada, M.; Sato, A.; Taguchi, T. J. Fluorine Chem. 2011, 132, 327-338. doi:10.1016/j.jfluchem.2011.03.007

47. Yamaki, Y.; Shigenaga, A.; Li, J.; Shimohigashi, Y.; Otaka, A. J. Org. Chem. 2009, 74, 3278-3285. doi:10.1021/jo900135t

48. Narumi, T.; Tomita, K.; Inokuchi, E.; Kobayashi, K.; Oishi, S.; Ohno, H.; Fujii, N. Tetrahedron 2008, 64, 4332-4346. doi:10.1016/j.tet.2008.02.076

49. Oishi, S.; Kamitani, H.; Kodera, Y.; Watanabe, K.; Kobayashi, K.; Narumi, T.; Tomita, K.; Ohno, H.; Naito, T.; Kodama, E.; Matsuoka, M.; Fujii, N. Org. Biomol. Chem. 2009, 7, 2872-2877. doi:10.1039/b907983a

50. Narumi, T.; Hayashi, R.; Tomita, K.; Kobayashi, K.; Tanahara, N.; Ohno, H.; Naito, T.; Kodama, E.; Matsuoka, M.; Oishi, S.; Fujii, N. Org. Biomol. Chem. 2010, 8, 616-621. doi:10.1039/B917236J

51. Niida, A.; Tomita, K.; Mizumoto, M.; Tanigaki, H.; Terada, T.; Oishi, S.; Otaka, A.; Inui, K.-i.; Fujii, N. Org. Lett. 2006, 8, 613-616. doi:10.1021/ol052781k

52. Chang, W.; Mosley, R. T.; Bansal, S.; Keilman, M.; Lam, A. M.; Furman, P. A.; Otto, M. J.; Sofia, M. J. Bioorg. Med. Chem. Lett. 2012, 22, 2938-2942. doi:10.1016/j.bmcl.2012.02.051

53. Dutheuil, G.; Pierry, C.; Villiers, E.; Couve-Bonnaire, S.; Pannecoucke, X. New J. Chem. 2013, 37, 1320-1325. doi:10.1039/C2NJ40891K

54. Villiers, E.; Couve-Bonnaire, S.; Cahard, D.; Pannecoucke, X. Tetrahedron 2015, 71, 7054-7062. doi:10.1016/j.tet.2015.06.093

55. Tomita, K.; Narumi, T.; Niida, A.; Oishi, S.; Ohno, H.; Fujii, N. Biopolymers 2007, 88, 272-278. doi:10.1002/bip.20676 


\section{License and Terms}

This is an Open Access article under the terms of the Creative Commons Attribution License

(http://creativecommons.org/licenses/by/4.0), which permits unrestricted use, distribution, and reproduction in any medium, provided the original work is properly cited.

The license is subject to the Beilstein Journal of Organic Chemistry terms and conditions:

(http://www.beilstein-journals.org/bjoc)

The definitive version of this article is the electronic one which can be found at:

doi:10.3762/bjoc.13.262 